\title{
İpotekli Konut Finansmanı Sisteminde Gelir/Servet Kısıtı ve Sonuçları: Yoksulluk, Gecekondu Olgusu ve TOKí İçin Bazı Öneriler
}

Yener COŞKUN

ycoskun@spk.gov.tr
Kürşat YALÇINER

yalciner@gazi.edu.tr

\section{Income/Wealth Constraint in Mortgage Finance and its Consequences: Some Suggestions for Poverty, Shanties and TOKI}

\begin{abstract}
However mortgage finance would support housing ownership, the system is mostly dsyfunctional in Turkey. Based on literature and comparative data analysis, we search the components of income/wealth constraint and its consequences in housing finance, as the essential constraint of the development of mortgage system and housing ownership. We first conclude that income/wealth constraint and shanty problems are fundamental socio-economic limits of the development of mortgage finance. Secondly, TOKI system, emerged also because of the above problems, has important risks. We suggest that optimal housing subsidy system may minimize current problems and support further development in mortgage system in Turkey.
\end{abstract}

Keywords

: Housing Finance, Mortgage, TOKI, Poverty, Shanties.

JEL Classification Codes : $\mathrm{R} 31, \mathrm{I3}, \mathrm{G} 21$.

\section{Özet}

İpotekli konut finansmanı sisteminin (İKFS) konut sahipliğini uygun finansman koşullarında desteklemesi beklenmekle birlikte, ülkemizde İKFS işlevini yerine getirememektedir. Literatür taraması ve karşılaştırmalı veri analizi çerçevesinde yapılan çalışmamızın araştırma sorusunu; İKFS'nin gelişmesinin ve konut sorununun asgariye indirilmesinin önündeki kısıtların başında gelen gelir/servet yetersizliği sorununun niteliği ve bu kapsamda karşılaşılan başlıca sonuçların neler olduğu oluşturmaktadır. Araştırma sonucunda, gelir/servet yetersizliğinin ve gecekondu sorununun IKFS'nin gelişmesinin önündeki temel sosyo-ekonomik sınırlar olduğu ve bunların da etkisiyle büyüyen TOKİ sisteminin risklerinin bulunduğu belirlenmiştir. Çalışmada bir çözüm önerisi olarak, konut finansmanına yönelik optimal bir teşvik sistemi tasarımının anılan sorunların asgariye indirilmesini ve İKFS’nin gelişmesini destekleyebileceği ileri sürülmektedir. 


\section{Acknowledgement}

This paper is expanded version of the following conference paper: "Yoksulluk, Gecekondu Olgusu ve İpotekli Konut Finansmanı Sisteminin Doğal Sinırları (Poverty, Shanties, and Natural Boundaries of Mortgage Finance). Coşkun, Yener \& Kürşat Yalçıner (2011), $12^{\text {th }}$ National Congress of Social Sciences, December 14-16, 2011, METU. Book of Abstract, p. 237. The views expressed in this paper, based on Ph.D dissertation of Dr. Yener Coşkun, are solely those of the authors and do not necessarily represent the affiliated institutions.

\section{Beyan}

$\mathrm{Bu}$ çalışma künyesi aşağıda yer verilen bildirinin önemli ölçüde gözden geçirilmiş ve düzeltilmiş halidir. "Coşkun, Yener \& Kürşat Yalçıner (2011), "Yoksulluk, Gecekondu Olgusu ve İpotekli Konut Finansmanı Sisteminin Doğal Sınırları”, 12. Ulusal Sosyal Bilimler Kongresi, 14-16 Aralık 2011, ODTÜ. Bildiriler Kitabı, s. 237. Yener Coşkun'un doktora tezi kapsamında hazırlanan bu çalışmada ileri sürülen görüşler yazarlara ait olup, yazarların bağlantılı olduğu kurumların görüşlerini yansıtmaz. 


\section{Giriş}

İpotekli konut finansmanı sistemi (IKFS), piyasa mekanizmasına dayalı konut finansmanında kullanılan önemli araçlar arasında yer almaktadır. 2000-2001 bankacılık krizi sonrasında ülkemiz ekonomisindeki yeniden yapılanma, 2000'li yılların ortalarından itibaren küresel finansal piyasalarda gözlenen likidite bolluğunun ülkemiz finansal piyasalarına olumlu yansımaları ve 2007 yılında yürürlüğe giren 5582 sayılı (Konut Finansmanı Sistemine İlişkin Çeşitli Kanunlarda Değişiklik Yapılması Hakkında) Kanun'dan kaynaklanan olumlu etkilerle birlikte İKFS ülkemiz gündeminde de önemli bir yere sahip olmuştur.

Fiyat erişilebilir konut finansmanını kolaylaştırması ve alt/orta gelir grubunun konut sorununun çözümlenmesine yönelik bir önceliğinin bulunması durumunda, IKFS'nin sosyal politika ve onun özelinde konut politikaları bağlamında önemli bir araç haline gelebileceği düşünülebilir. İKFS'nin gelişmesi formel konut finansmanının yaygınlaşmasını sağlayacak koşulların varlığı ile ilişkilidir. İKFS birincil piyasasındaki kredi kurumları tarafından tahsis edilen ipotekli konut kredilerine özellikle alt/orta gelir grubunun erişiminin artması İKFS'nin gelişmesinin ön koşulları arasında yer almaktadır. Bununla birlikte, diğer gelişmekte olan ülkelerde (GOÜ) olduğu gibi, ülkemizde de gelir/servet yetersizliği/eşitsizliği, düşük ücretli/kayıt dışı istihdamın ve işsizliğin yaygın olması, istikrarsız piyasa koşullarının ve kurumsal eksiklerin konut finansmanını güçleştirmesi ve konut edinimine yönelik kamusal teşviklerin yetersiz olması gibi sosyoekonomik koşullar; konut gereksinimi olan alt/orta gelir grubunun İKFS'ye erişimini olumsuz yönde etkilemektedir.

Cumhuriyet tarihi boyunca ülkemizde etkili/sürdürülebilir konut politikalarının bulunmaması, alt/orta gelir grubunun konut kredisine erişiminin yapısal nedenlerle yetersiz kalması ve böylelikle konut sorununun önemli boyutlara ulaşması önemli sosyoekonomik/politik sonuçların ortaya çıkmasına neden olmuştur. Bu sonuçların başında, konut sorununun (politik/ekonomik/sosyal anlamda içsel tutarlılığ bulunan bir olgu olarak) gecekondu kiracılı̆̆ı/sahipliği yoluyla çözümlenmesi gelmektedir. Söz konusu olgu, paradoksal biçimde, taşınmaz-finans sektörleri arasındaki ortak büyümeye dayalı ilişkiyi bozarak, İKFS'nin (ve dolayısıyla finansal sistemin) az gelişmişliğini daha da artırmaktadır. Ayrıca son dönemde yeniden güncellik kazanan kentsel dönüşüm çalışmaları, gecekondu ekonomisinin her yönüyle ülke gündeminde belirleyici işlevini sürdürdüğüne işaret etmektedir. Konut sorununun, konut finansmanına yönelik piyasa koşullarının sosyal politika öncelikleri çerçevesinde yönlendirilmesine dayalı bir yapı çerçevesinde, çözümlenememesinin neden olduğu diğer bir sonuç ise; 2000'li yılların ortalarından itibaren TOKİ sisteminin yeniden önem kazanmasıdır. Çok amaçlı ve karmaşık bir yapısı bulunan TOKİ sisteminin konut sorununa çözüm üreten bir başarıya işaret ettiği açıktır. Ancak söz konusu yapının, çarpıcı sosyo-politik ögelere sahip denetim 
dışı bir kamu ekonomisi yaratması da aynı derecede dikkat çekicidir. TOKİ sistemi ile olağan dışı ölçülerde büyüyen kamu ekonomisi ve kamu gücüne dayalı rant yaratma mekanizması, piyasa odaklı politikaların egemen olduğu bir yapı içinde önemli bir ideolojik çelişkiye işaret etmektedir. Ancak daha da önemlisi, çeşitli riskleri ve sorunları da beraberinde getirmektedir. Dolayısıyla İKFS'nin gelişmesinin önündeki güncel sorunların ve bu sorunlara yönelik çözüm önerilerinin belirlenmesi; konut (finansmanı) sorununun sürdürülebilir bir çerçevede çözümlenmesinin ve finansal sistemin gelişme koşullarının belirlenmesinin yanında, ülkemizdeki ekonomik, siyasal ve sosyal yapının konut sorunu/finansmanı üzerinden yeniden tasarlanması açısından da dikkat çekici bir araştırma konusu niteliği taşımaktadır.

Literatür taraması ve karşılaştırmalı veri analizi çerçevesinde yapılan çalışmamızın araştırma sorusunu; İKFS'nin gelişmesinin ve konut sorununun asgariye indirilmesinin önündeki kısıtların başında gelen gelir/servet yetersizliği sorununun niteliği ve bu kapsamda karşılaşılan başlıca sonuçların neler olduğu oluşturmaktadır. Bu kapsamda gecekondu olgusundaki ve TOKİ sistemindeki gelişmelerin konut finansmanında karşılaşılan gelir/servet yetersizliği sorunu ile olan ilişkisi ve İKFS'nin gelişim sürecine etkileri de incelenmiştir. Çalışmada ortaya konulan çözüm önerilerinin ve yeni araştırma konularının akademik çalışmalar kadar sektör açısından da dikkat çekici bulunabileceği düşünülmektedir. Çalışmada öncelikle kavramsal düzlemde ve ülkemiz örneğinde konut sorunu incelenmiş, ardından İKFS kavramı ve IKFF'nin gelişimine yönelik ön koşullar analiz edilmiştir. Çalışmada ayrıca İKFS'nin başarımını kısıtlayan sorunların başında gelen gelir/servet yetersizliği, bunun da etkisiyle ortaya çıkan gecekondu olgusu ve TOKİ'nin finansal risklerine yönelik incelemeler sonrasında, konut finansmanında gelir/servet yetersizliğinin optimal teşvik sistemlerinin tasarımı yoluyla giderilmesine yönelik önerilere yer verilmiştir.

\section{Konut Sorunu}

\subsection{Kavramsal Düzlemde Konut Sorunu}

Toplumsal, siyasal, ekonomik ve kültürel boyutları bulunan konut sorununun bileşenlerinin ortaya konulabilmesi çok yönlü bir değerlendirmeyi gerektirmektedir. Karmaşık sosyo-ekonomik/politik süreçlerin egemen olduğu modern demokratik toplumlarda konut sorununun tam olarak çözülmesinin basit bir formülü bulunmamaktadır. Ancak konut sorununun asgariye indirilmesi çağdaş toplumların sosyal politika öncelikleri arasında yer almaktadır.

Ekonomik bağlamda değerlendirildiğinde konut sorunu; konut finansmanına yönelik piyasa koşulları, merkezi/yerel düzeydeki konut teşvik politikaları ve hanehalkının sosyo- ekonomik yapısı gibi çok yönlü değişkenlerle ilişkilidir. Hanehalkı ekonomisi 
açısından, konut sahipliğinin kredi ile finansmanı önemli bir gelir akımının ve servet birikiminin varlığını gerektirmektedir. Bu süreçte servet birikimi ön ödemenin ve gelir akımı da aylık konut kredisi geri ödemelerinin finansmanı açısından önemlidir. Konut ediniminin makroekonomik değişkenlerin gelişimi, bölüşüm süreçleri ve konut politikaları ile yakın ilişkisi vardır. Örneğin istihdam yaratan, istikrarlı reel büyüme gösteren, gelir bölüşümünün göreli adil ve yoksulluğun sınırlı olduğu, konut politikalarının konut sahipliğini desteklediği, fiyat istikrarının ve finansal sistemin işlevselliğinin bulunduğu bir ekonomi için konut sorununun çözüme kavuşturulmasının görece kolay olabileceği düşünülebilir. Bununla birlikte küresel kriz gelişmiş ve göreli istikrarlı ekonomilerde bile piyasa ekonomisine dayalı konut finansmanının önemli riskler içerdiğini ve konut sorununun çözüme kavuşturulmasının gelişmiş ekonomilerde bile kolay olmayabileceğini ortaya koymuştur.

Yoksulların konut sorununa yönelik politikalar; politik hayatı ve kamu bütçesi yönetimini etkilemektedir. Bu bağlamda, barınma gereksiniminin hukuka aykırı olarak karşılanmasının sembolü olarak da görülebilecek, gecekonduların ülkemizdeki gelişme sürecinin merkezi/yerel siyasi karar alma mekanizmasının dışında değerlendirmek mümkün görünmemektedir. Benzer biçimde, merkezi/yerel yönetimlerin konut sorununa yönelik davranışlarının, siyasi karar alma mekanizmaları ve seçmen tercihlerinin yönlendirilmesi ile ilişkisinin bulunduğu söylenebilir. Ayrıca son dönemde yeniden güncellik kazanan kentsel dönüşüm çalışmaları, gecekondu ekonomisinin her yönüyle ülke gündeminde belirleyici işlevini sürdürdüğüne işaret etmektedir.

Sosyal, ekonomik, kültürel ve özellikle demografik yap1 konut sorununun gelişimi üzerinde etkili olmaktadır. Kentleşme, sanayileşme ve iç göç gibi etkenler özellikle GOÜ'de konut sorununun ivme kazanmasına neden olmaktadır. Konuyu ülkemiz örneğinde değerlendiren Mengi ve Keleş (2003: 11), 1980 yılında \%43,9 olan kentli nüfus oranının, 2000 yılında \%65'e yükseldiğini belirtmektedir. Demir ve Palabıyık (2005: 3) ise Türkiye'de köyden kente göçün, yaşlı nüfusun, evlenmemiş insan sayısındaki artışın, bölünen ve birey sayısı giderek azalan ailelerin konut talebinde artışa neden olduğunu belirtmektedir. Bu kapsamda, demografik değişimlerin konut gereksinimini artırmasının da etkisiyle, konut sorununun yakın gelecekte de önemini koruyacağı ve formel/informel konut piyasasındaki gelişmelerin ülkenin sosyo-ekonomik/politik gündemini belirlemeye devam edeceğini ileri sürmek mümkündür.

\subsection{Türkiye'de Konut Sorunu}

Birleşmiş Milletler (2008: 2) de yer alan belirlemeler de dikkate alınarak, konut arzının yetersiz olmasına neden olan başlıca etkenler; mevcut konutlara göre hanehalkı sayısının (evsiz hanehalkları da dâhil olmak üzere) fazla olması, yoğunluk (örneğin ayrı bir oda gereksinimi duyan evli çiftlerin sayısı) ve kullanım dışı/modası geçmiş konutlar olarak 
belirlenebilir. Ülkemiz konut piyasasına yönelik veri tabanlı makro ölçekli bir gözlemin, konut piyasasındaki arz, talep ve fiyat değişimlerini etkileyen değişkenler hakkında bilgi sunabileceği düşünülmektedir. $\mathrm{Bu}$ bağlamda ülkemizdeki niceliksel/niteliksel konut açığına ilişkin veri ve değerlendirmeler aşağıda incelenmektedir.

2000 yılı bina sayımı istatistiğine göre ülkemizdeki bina sayısı 7,8 milyon adetdir. Söz konusu binaların yaklaşık 5,9 milyonu ise konuttur (TÜiK, 2001: 24). Bayraktar (2008: 9) İstanbul'da bulunan 3 milyonun üzerindeki konutun yarısından fazlasının ve bütün kentlerdeki 15 milyonun üzerindeki konutun $\% 60$ 'dan fazlasının yenilenmesi gerektiğini belirtmektedir. European Mortgage Federation (2007: 128-130) konut arzını belirleyen unsurları; yapımına izin verilen konut sayısı, yapımına başlanan konut sayısı ve tamamlanan konut sayısı olarak belirlemiştir. Aşağıda yer alan çizelgeden de anlaşılacağı üzere ülkemiz söz konusu konut arzı ölçütleri açısından 2004-2006 döneminde çoğu Avrupa ülkesinin gerisinde görünmektedir.

Tablo: 1

Türkiye'deki Konut Arzı Gelişmelerinin Seçilmiş AB Ülkeleri İle Kıyaslanması

\begin{tabular}{|l|c|c|c|c|c|c|c|c|c|}
\hline \multirow{2}{*}{ Ülke } & \multicolumn{3}{|c|}{ Yapımına Başlanan } & \multicolumn{3}{c|}{ Tamamlanan } & \multicolumn{3}{c|}{ Yapımına İin Verilen } \\
& \multicolumn{3}{|c|}{ Konut Sayıs1 } & \multicolumn{3}{c|}{ Konut Sayıs1 } & \multicolumn{3}{c|}{ Konut Sayı1 } \\
\hline & 2004 & 2005 & 2006 & 2004 & 2005 & 2006 & 2004 & 2005 & 2006 \\
\hline Danimarka & 29,426 & 31,400 & 26,922 & 27,152 & 27,580 & 26,327 & 30,694 & 35,618 & 29,180 \\
\hline Almanya & $\mathrm{v} / \mathrm{y}$ & $\mathrm{v} / \mathrm{y}$ & $\mathrm{v} / \mathrm{y}$ & 278,019 & 238,977 & 248,435 & 268,123 & 240,468 & 247,541 \\
\hline İspanya & 691,027 & 716,219 & 760,179 & 496,785 & 524,479 & 584,881 & 687,051 & 729,652 & 865,561 \\
\hline Fransa & 363,400 & 410,200 & 420,900 & $\mathrm{v} / \mathrm{y}$ & $\mathrm{v} / \mathrm{y}$ & $\mathrm{v} / \mathrm{y}$ & 460,800 & 511,700 & 561,700 \\
\hline Polonya & 97,000 & 102,038 & 137,962 & 108,123 & 114,060 & 115,187 & 105,831 & 115,862 & 160,545 \\
\hline İngiltere & 227,875 & 226,766 & 231,583 & 203,376 & 209,560 & $\mathrm{v} / \mathrm{y}$ & $\mathrm{v} / \mathrm{y}$ & $\mathrm{v} / \mathrm{y}$ & $\mathrm{v} / \mathrm{y}$ \\
\hline İsviçre & 52,652 & 57,340 & 60,232 & 36,935 & 37,958 & 41,989 & 30,923 & 31,928 & 35,416 \\
\hline Yunanistan & $\mathrm{v} / \mathrm{y}$ & $\mathrm{v} / \mathrm{y}$ & $\mathrm{v} / \mathrm{y}$ & $\mathrm{v} / \mathrm{y}$ & $\mathrm{v} / \mathrm{y}$ & $\mathrm{v} / \mathrm{y}$ & 80,842 & 95,032 & 81,301 \\
\hline Türkiye & $\mathrm{v} / \mathrm{y}$ & $\mathrm{v} / \mathrm{y}$ & $\mathrm{v} / \mathrm{y}$ & 39,540 & 64,126 & 65,800 & 72,005 & 114,254 & 108,109 \\
\hline
\end{tabular}

v/y: Veri yok. Kaynak: European Mortgage Federation (2007: 128-130).

Genel olarak taşınmaz sektörüne yönelik sağlıklı veri altyapısı ülkemizde henüz mevcut değildir. Söz konusu sorun konut sektöründe de bulunmaktadır. Nitekim Gürbüz (2002: 22) TÜİK'in sağlıklı veri tabanına dayalı konut stoku ve ihtiyacını henüz belirleyemediğini vurgulamaktadır. Yazarın söz konusu belirlemesinin halen önemli ölçüde geçerliliğini koruduğu söylenebilir. Ülkemizdeki konut sorununun niceliksel boyutlarının belirlenmesinde kentlerdeki konut gereksiniminin çeşitli ölçütler çerçevesinde ne ölçüde karşılanabildiğinin belirlenmesi önem taşımaktadır. İlk olarak kamu sabit sermaye yatırımlarında konuta ayrılan payın oldukça düşük olduğunu belirtmek gereklidir. Bu kapsamda, 2007-2013 dönemini kapsayan dokuzuncu kalkınma planında, sektörel kamu sabit sermaye yatırımlarının \%0,8'ine karşılık gelen 1,3 milyar TL'lik bölümünün konuta ayrılması planlanırken, gerçekleşme oran ve tutarı \%1,6 ve 6,4 milyar TL olmuştur. 2014-2018 dönemini kapsayan onuncu kalkınma planında ise kamu sabit sermaye 
yatırımlarının \%1'ine karşılık gelen 4,2 milyar TL'sinin konut yatırımlarına ayrılması planlanmıştır (DPT, 2006: 58; 2013: 92). Tablo: 2'de yer alan kalkınma planlarındaki konut açığı verileri değerlendirildiğinde, konut gereksiniminin karşılanma oranının yetersiz olduğu gözlenmektedir.

Tablo: 2

Planlı Dönemde Konut Gereksinimi ve Konut Açığı

\begin{tabular}{|l|c|c|c|c|}
\hline Dönemler* & Gereksinim (A) & Gerçekleşme (B) & Gereksinimin Karş1lanan Kısmı (B/A, \%) & Konut Açı̆̆ (A-B) \\
\hline 1.BYKP & 418.793 & 138.212 & 30,3 & 280.581 \\
\hline 2.BYKP & 900.000 & 360.761 & 40,0 & 539.239 \\
\hline 3.BYKP & 1.220 .000 & 499.312 & 40,9 & 720.688 \\
\hline 4.BYKP & 1.705 .065 & 607.721 & 35,6 & 1.097 .344 \\
\hline 5.BYKP & 1.491 .000 & 943.830 & 63,6 & 547.170 \\
\hline 6.BYKP & 1.838 .000 & 1.241 .778 & 67,6 & 596.222 \\
\hline 7.BYKP & 2.600 .000 & 1.247 .879 & 48,0 & 1.352 .121 \\
\hline 8.BYKP & 3.075 .000 & - & - & - \\
\hline 9.KP & 3.500 .000 & 3.200 .000 & 91,4 & 300.000 \\
\hline 10. KP & $4.100 .000(\mathrm{~T})$ & - & - & - \\
\hline
\end{tabular}

*BYKP: Beş yıllık kalkınma planı. KP: Kalkınma planı. T: Tahmin. Kaynak: Aydın (2003: 47); DPT (2013: 147).

Sekizinci beş yıllık kalkınma planı konut özel ihtisas komisyonu raporunda, ülkemizde yılda yaklaşık 400 bin konut gereksinmesinin bulunduğuna ve serbest piyasa ekonomisinin işleyişi içinde yeterli konut üretiminin gerçekleştirilemediğine yer verilmiştir (DPT, 2001: 66). Buna karşılık TÜBİTAK ise, söz konusu sayının ne tür konutları temsil ettiği konusuna açıklık getirilmediğini belirtmektedir. Anılan çalışmada, kaçak yapılaşma (ruhsatsız veya affa uğramamış yapılaşma), güçlendirilmesi/rehabilitasyonu gereken konutlar ve çağdaş ölçütlerle kullanılamayacak durumda olup yeniden yapımı gereken konutlar gibi yapıların, bu verinin kapsamında olup olmadıklarının veya hangi ölçüde dikkate alındıklarının bilinmediği vurgulanmaktadır (Tübitak, 2003: 17).

Tekeli (1994: 121) de konut sorununun konut açığı hesaplarını ön plana alan bir söyleme dayandırılmasının; konut sorununun çok yönlü niteliğinin kavranılmasını güçleştirdiğini, konut açığı üzerinde duran söylemin konut sorununu sadece yapılacak yeni konutların sayısının artıılmasına indirgeyerek konut/çevre kalitesi ile var olan konut stokunun değerlendirilmesi sorunlarının göz ardı edilmesine neden olduğunu belirtmektedir. Keleş (2006: 432), açık ya da gözle görülen konut açığının nicel bir özellik olduğunu, bunun yanında bir de barınma koşullarının niteliğinden kaynaklanan gizli konut açığının bulunduğunu belirtmektedir. Bu bağlamda Yazar konutların aşırı derecede 
kalabalık olmasının gizli konut açığının bir göstergesi olduğunun ve gizli konut açığının da açık konut açığı gibi konut kestiriminde hesaba katılması gerektiğinin altını çizmektedir. ${ }^{1}$

Ülkemizdeki konut sorununa niteliksel açıdan bakıldığında, ülkemizin sosyoekonomik kalkınmışlık seviyesinin doğal bir sonucu olarak, sorunlu bir tablo ile karşılaşılmaktadır. TÜİK tarafından yayımlanan nüfus ve konut araştırması 2011 sonuçlarına göre, 2 Ekim 2011 tarihinde ülkemizdeki hane sayısı 19.481.678 iken ve ortalama hane halkı büyüklüğü ise 3,8'dir. Konutunun içinde borulu su sistemi olan hane halklarının oranı $\% 97,4$ 'tür. Konutunda tuvalet bulunan hane halklarının oranı $\% 92,5$ ve konutunda banyo bulunan hane halklarının oranı ise \%97,2'dir (TÜIK, 2013)². Öte yandan TÜIK (2001: 6) 2000 yılında pissu tesisatının bağlı olduğu ünitesi kanalizasyon olan binaların toplam bina sayısı içindeki payı \%68 iken, fosseptiğin \%25 ile ikinci sırada yer aldığını belirtmektedir. Bir başka açıdan veri seti sunmak gerekirse, TÜIK, Hanehalkı Bütçe Anketi'ne göre ülkemizde 2005 yılı itibarı ile iyileştirilmiş su kaynaklarına sürdürülebilir ulaşımı sağlanmış nüfusun oranı \%94,8'dir. Anılan TÜiKK anketine göre 2005 yılı itibarı ile yeterli atık sistemine sahip nüfusun oranı ise $\% 82,6$ olarak gerçekleşmiştir. TÜIK, 2000 genel nüfus sayımına göre, 2000 yılı itibarı ile odabaşına düşen kişi sayısının ${ }^{3} 1,27$ olduğunu belirtmektedir ${ }^{4}$.

Niceliksel/niteliksel olarak önemli boyutlara ulaştığı tartışma konusu edilse de, ülkemizdeki konut sorununun sağlıklı veri altyapısı çerçevesinde değerlendirilemediğini belirtmek gereklidir. Yapısal nedenleri bulunan konut sorununun mevcut yaklaşım ve düzenleme yapısı (bkz. Coşkun, 2011a: 9) ile uzun dönemde çözümlenmesi kolay görünmemekle birlikte ${ }^{5}$, son yıllarda İKFS'nin konut sorununun çözülmesinde önemli bir rol üstlenebileceği gündeme getirilmiştir. Bu kapsamda İKFS'nin gelişme koşullarının incelenmesi, İKFS çerçevesinde konut sorununun çözülmesinin mümkün olup olmadığının anlaşılması açısından önemlidir.

1 Ülkemizde konut açı̆̆ı değil, konut fazlası bulunduğuna ilişkin dikkat çekici görüşler bulunmaktadır (örnek olarak bkz. Sarı, 2007; Balamir, 2010; Türel, 2012). Bu kapsamda, yapı ruhsat/izin belgeleri, konut satışarı, hane halkı sayısındaki değişim gibi verilerin incelenmesinin konut açı̆̆lffazlası tartışmalarında kısmen yol gösterici olabileceği düşünülmektedir.

Önceki TÜIK verilerinde ise ülkemizde mevcut 15.070 .093 adet konutun 2.409 .858 adedinde tuvaletin konutun dışında kaldı̆̆ına, 170.886 adet konutta tuvalet bulunmadiğına, konutların 380.513 adedinde banyo ve 319.944 adedinde mutfağın konutun dışında kaldığına, 542.328 adet konutta banyo ve 403.135 adet konutta mutfak bulunmadığına, 762.789 adet konutta borulu suyun konutun dışında kaldığına ve 874.984 adet konutta ise borulu suyun bulunmadığına yer verilmiştir (TÜIK, 2012).

3 Barınma yoğunluğu olarak bilinen odabaşına nüfus rakamları konutların nitel yönden yetersizliğinin açık bir belirtisidir (Keleş, 2006: 455).

4 TÜIK verileri: <http://nkg.tuik.gov.tr/form.asp?id=2>, (Erişim Tarihi: 12.10.2012).

5 Ülkemizdeki konut sorununun çözümüne yönelik öneriler için bkz. Coşkun (2011b; 2011c). 


\section{3. İpotekli Konut Finansmanı Sistemi ve Gelişim Koşulları}

\subsection{Kavram}

Konut yatırımının temel özellikleri; göreli ölçeğinin büyük olması ve uzun bir yatırım dönemi gerektirmesidir. Söz konusu özellikler nedeniyle konut yatırımı yüksek tutarlı finansman gerektirmektedir. Konut finansman sisteminin amacı ise; üreticiye ve konut talebinde bulunan tüketicilere finansman sağlanmasıdır (Lea, 2009: 29). İKFS, konut finansmanının piyasa mekanizmasına tabi kurum, kural ve araçlar çerçevesinde yapılmasıdır. IKKFS kavramının yaygın kullanımı konut finansmanının salt piyasa mekanizması koşullarında yapılmasını ima etmektedir. Bununla birlikte, gelişmiş/gelişen ülkelerdeki İKFS'nde önemli kamusal teşviklerin bulunabildiği ve IKFS'nin sosyal nitelikler kazandığı da görülmektedir. Söz konusu olgu İKFS'nin salt piyasa mekanizmasına dayalı bir konut finansman türü olarak görülmemesi gerektiğine işaret etmektedir.

Konut finansmanı ve konut sorunu yakından ilintili kavramlardır. Konut finansman biçimlerinin toplumun geniş kesimlerince yaygın/sürdürülebilir biçimde kullanılabilir olması, konut sorununun çözülmesinde önem taşımaktadır. Konut politikalarının konut sorununun çözülmesi sürecindeki başarımı ise; farklı toplumsal kesimlere yönelik alternatif/ sürdürülebilir konut finansmanı politikalarının başarılı şekilde uygulanabilmesi ile ilişkilidir. Bu çerçevede IKFS'ye yönelik temel beklenti; nitelikli konutlara, ortalama gelir sahibi hanehalklarının uygun finansman koşulları çerçevesinde erişebilirliğinin artırılmasıdır. Ancak söz konusu beklentinin gelişmiş/gelişen ülkelerdeki alt/orta gelir grubu açısından karşılandığını söylemek güçtür. Ayrıca küresel kriz sürecinde piyasa mekanizmasına dayalı İKFS'nin göreli başarımının daha da azaldığı görülmektedir. ${ }^{6}$

Ülkemizdeki İKFS tasarımının piyasa merkezli olmasına çok sayıda örnek vermek mümkündür. Bu kapsamda, ülkemizdeki IKKFS'de konut kredisi tahsisini alt/orta gelir grubu açısından cazip kılacak (konut kredisi faiz giderlerinin kredi kullananların ödeyeceği vergiden indirilmesi gibi) teşvik/sübvansiyon sistemleri bulunmamaktadır. Ayrıca yine düşük gelir gruplarının konut sahibi olmasını destekleyebilecek, sosyal yönleri bulunan tamamlayıcı finansman teknikleri (sözleşme sistemi, mikrofinansman vb.) ve ipotek sigortacilığı da ülkemizde gelişmemiştir. Öte yandan, faaliyete geçirilememekle birlikte İpotek Finansman Kuruluşu'nun (IFK) piyasaya likidite sağlama işlevinin piyasa koşullarında gerçekleştirilmesinin öngörülmesi ve menkulleştirme araçlarına yönelik

6 Krizin başlıca nedenleri arasında yeralan kredilendirme ve değerleme sorunları ipotekli konut finansmanı birincil ve ikincil piyasasının yeni bir tasarıma ihtiyacı olduğunu göstermektedir (Coşkun, 2010: 224). Ülkemize yönelik bir model önerisi için bkz. Coşkun (2013a). 
düzenlemelerin konut sorunu yaşayan kesimlere yönelik teşvikler içermemesi dikkat çekicidir. Daha da önemlisi genel olarak bakıldığında, alt/orta gelir grubu lehine sosyal hiçbir yönü bulunmayan düzenlemeler kapsamında şekillenen İKFS; alt/orta gelir grubunun sorunlarını dikkate alan bir anlayış çerçevesinde konut sorununu çözmek yerine, bankacılık sektörünün karlılık/risk yönetimi hedeflerinin hukukunu oluşturacak biçimde, tüketiciler aleyhine bankalara aşırı hukuksal yetkiler tanınmasına yönelmiştir. Bu nedenle, 5582 sayılı Kanun'un konut sorununun çözümüne yönelik bir tasarım olarak kabul edilemeyeceği ve 1980 sonrasında hız kazanan neo-liberal ekonomik çerçevenin konut (finansmanı) piyasalarına uygulanmasına zemin hazırlama amacını taşıdığı düşünülmektedir (bkz. Coşkun, 2013a, 2013b).

\section{2. İKFS'nin İşlevsellik Koşulları}

Dünya Bankas1 konut finansman sisteminin konut tüketicileri/üreticileri/finansman kurumları açısından işlevsellik kazanmasının koşullarını belirlemiştir. Aşağıda yer alan tablodan da anlaşılacağı üzere, konut finansman sisteminin konut tüketicisi, üreticisi ve finansman kurumları açısından etkin biçimde işleyebilmesi; piyasa etkinliğine ilişkin birçok koşulun varlığıyla ilişkilidir.

2007 yılında ABD eşik altı ipotek kredileri sektöründe ortaya çıktıktan sonra, ABD finans/taşınmaz piyasalarında büyük bir finansal yıkıma neden olan ve etkilerini küresel ölçekte hala sürdüren küresel finansal kriz, konut piyasalarının tasarımı açısından da önemli dersler içermektedir. Bu kapsamda, küresel kriz sürecinde sistemik risk yönetiminde yaşanan başarısızlıkların bir nedeni de; ABD konut/finans piyasalarındaki resmi disiplin (düzenleme/ denetim/yaptırım) yapısının etkin olmamasıdır. Bu kapsamda, ilk olarak ABD Merkez Bankası FED'in 2003 yılı sonrasında izlediği faiz politikalarının konut balonunun oluşmasında etkili olduğu görülmektedir. Krizin gelişmesinde etkili olan diğer kamu politikası hataları arasında; düzenleme/denetim süreçlerinin etkin olmaması, konut edinimine yönelik teşvik sisteminin olumsuz etkilerinin göz ardı edilmesi, kredi tahsisi ve menkulleştirme süreçlerindeki risklerin öngörülememesi, finansal aracıların risk yönetim ve sermaye yetersizliklerine tedbir alınamaması ve gölge bankacılık/yeni finansın kuralsız düzeninin olumsuz etkilerinin yönetilememesi de yer almaktadır (bkz. Coşkun, 2013a).

2007/Haziran'da yürürlüğe giren 5582 sayılı Konut Finansmanı Sistemine İlişkin Çeşitli Kanunlarda Değişiklik Yapılması Hakkında Kanun ile birlikte İKFS'ye dayalı konut edinimi güncellik kazanmıştır. İKFS'nin fiyat erişilebilir konut edinimini kolaylaştırması konut sorununun çözülmesine katkı sağlayabilir. Ayrıca alt/orta gelir grubunun konut sorununun çözümlenmesine yönelik bir önceliğinin bulunması durumunda İKFS'nin konut politikaları bağlamında önemli bir araç haline gelebileceği de düşünülebilir. Bununla birlikte, yukarıdaki tabloda yer alan koşulların özellikle GOÜ'de 
piyasa koşullarında sağlanmasının kolay olmayabileceği dikkate alındığında, diğer koşulların yanı sıra, etkin bir teşvik mekanizması ile desteklenmeyen İKFS'nin konut sorununun çözülmesine yönelik katkısının sınırlı olabileceğini de belirtmek gereklidir.

Tablo: 3

\section{İşlevsel Konut Piyasasında Konut Tüketicileri, Üreticileri ve Finansman Kurumları}

\begin{tabular}{|l|l|l|}
\hline \multicolumn{1}{|c|}{ Konut Tüketicileri } & \multicolumn{1}{|c|}{ Konut Üreticileri } & \multicolumn{1}{c|}{$\begin{array}{c}\text { Konut Finansman (Kredi) } \\
\text { Kurumları (KFK) }\end{array}$} \\
\hline $\begin{array}{l}\text { Her hanehalkı için güvenli, yeterli ve } \\
\text { müstakil konut seçeneğinin bulunması }\end{array}$ & $\begin{array}{l}\text { Konut sözleşmelerinin } \\
\text { uygulanabilir olması }\end{array}$ & $\begin{array}{l}\text { KFK nın korunması için taşınmaz } \\
\text { hakları/haciz/yasal yararlanmanın } \\
\text { hukuken tanıml1/yeterli olması }\end{array}$ \\
\hline $\begin{array}{l}\text { Konut fiyatlarının istikrarlı olması ve } \\
\text { etkin bir seçim yapılmasına olanak } \\
\text { verecek yeterli bilginin varlığ1 }\end{array}$ & $\begin{array}{l}\text { Konuta yönelik arazi arzının } \\
\text { yeterli, uygun maliyetli ve } \\
\text { altyapılı olması }\end{array}$ & $\begin{array}{l}\text { KFK nın rekabetçi bir finansal } \\
\text { sistemde faaliyet göstermesi }\end{array}$ \\
\hline $\begin{array}{l}\text { Farklı fiyat aralıkları için finansman } \\
\text { olanaklarının bulunması ve finansman } \\
\text { olanaklarının rekabetçi bir yapı içinde } \\
\text { sunulması }\end{array}$ & $\begin{array}{l}\text { Yapı malzemesi ve kalifiye } \\
\text { işgücünün makul } \\
\text { maliyetlerinin olması }\end{array}$ & $\begin{array}{l}\text { Mevduatın; uzun dönemli, karlı ve reel } \\
\text { faize dayalı ipotek kredisine olanak } \\
\text { verecek vadeye sahip olması }\end{array}$ \\
\hline $\begin{array}{l}\text { Konut kredisinden kaynaklanan } \\
\text { yükümlülüklerin hanehalkı bütçesinde } \\
\text { makul bir yere sahip olması }\end{array}$ & $\begin{array}{l}\text { Yeterli finansman } \\
\text { olanaklarının bulunması }\end{array}$ & $\begin{array}{l}\text { Ípotekli kredi ürünlerinin KFK için } \\
\text { yeterli koruma sağlaması }\end{array}$ \\
\hline $\begin{array}{l}\text { Piyasada satılık/kiralık konut konusunda } \\
\text { seçeneklerin bulunması }\end{array}$ & $\begin{array}{l}\text { Konut talebinin özelliklerine } \\
\text { ilişkin yeterli bilginin } \\
\text { bulunması }\end{array}$ & $\begin{array}{l}\text { Kredi tahsisinden kaynaklanan } \\
\text { risklerin yönetimi amacıyla ikincil } \\
\text { piyasaların varlığı }\end{array}$ \\
\hline $\begin{array}{l}\text { Hanehalkının konut ve komşuluğa ilişkin } \\
\text { politika kararlarına katılım gösterebilmesi }\end{array}$ & $\begin{array}{l}\text { Konut yatırımlarının yeterli } \\
\text { getiriye sahip olması }\end{array}$ & $\begin{array}{l}\text { İpotekli konut finansmanından } \\
\text { kaynaklanan risklere karş1 KFK'ları } \\
\text { koruyacak kurumların varlığı }\end{array}$ \\
\hline
\end{tabular}

Kaynak: Dünya Bankasl (1993, Aktaran: Erbaş ve Nothaft, 2002: 12).

1980 sonrasında ivme kazanan neo-liberal politikaların da etkisiyle, bankacılık sektörünün karlı faaliyet sahası olarak gördüğü, İKFS'nin GOÜ’de başarılı olmasının önkoşulları bulunmaktadır. Söz konusu önkoşulların ülkemizde önemli ölçüde karşılanamaması İKFS'nin de yeterince gelişememesine neden olmuştur. Konut politikalarındaki tutarsızlıklar, taşınmaz ekonomisi-finans piyasaları (banka, sigortacılık, sermaye piyasaları) arasındaki bağın etkin olmaması ve İKFS birincil/ikincil piyasalarındaki kurumsal yetersizlikler gibi diğer sorunların yanısıra, İKFS'nin ülkemizde yeterince gelişme gösterememesinin temel nedenlerinin başında; gelir yetersizliğinin (yoksulluk) ve (informel ekonomi ve) informel konut finansman sistemlerinin yaygın/etkili olmasının önemli bir payı bulunmaktadır. Bu bağlamda, ülkemizdeki gecekonduya dayalı konut edinme/üretimi/finansmanı biçimlerinin, hukuksal süreçler ve mülkiyet ilişkileri gibi

7 Farkl fiyat aralıkları için finansman olanaklarının bulunması; zaman içinde konuta yönelik harcamaların etkisinin azalması (smoothing) ve hanehalkinın tasarrufa/yatırıma yönelmesine olanak tanınması amaçları çerçevesinde önemlidir (Dünya Bankası, 1993, Aktaran: Erbaş ve Nothaft, 2002: 12). 
konularda formel konut edinme sisteminin dışında kalması ve İKFS'nin gelişimini olumsuz yönde etkilemesi dikkat çekicidir. İzleyen bölümde de değerlendirildiği üzere, konut sorununu yansıtan önemli ölçütlerin başında gelen gecekondu olgusu; aynı zamanda İKFS'nin gelişimi için de doğal bir sınır oluşturmaktadır.

\section{4. İKFS'nin Doğal Sınırları ve Sonuçları}

İKFS piyasa mekanizmasına dayalı konut finansmanı seçenekleri sunmaktadır. Söz konusu sistem, ülkemizde olduğu gibi, konut finansmanına yönelik neredeyse hiç kamusal destek olmaksızın veya birçok ülkede olduğu gibi konut finansmanına yönelik çeşitli kamusal destekler çerçevesinde şekillendirilebilir. İKFS'nin gelişmesinin önündeki temel sorunların başında, fiyata erişebilirliği olumsuz etkileyen, konut talep eden hanehalklarının gelir/servet yetersizliği gelmektedir. Gelir/servet yetersizliği sorunu, ülkemizde gecekondu yerleşimlerinin artmasına, konut sorununa tepki olarak merkezi/yerel kamu girişimciliğinin önemli boyutlarda büyümesine ve ülkemizdeki İKFS'nin yeterince gelişememesine neden olmuştur.

\section{1. İKFS'nin Doğal Sınırları: Konut Finansmanında Gelir/Servet Yetersizliği}

IKFS'nin formel/informel konut finansman modellerine seçenek teşkil etmesi; sistemin taşınmaz ve finans piyasalarını düşük işlem maliyeti/yüksek etkinlikle ilişkilendirmesi, finans piyasalarının uzun vadeli/düşük faizli konut finansmanını desteklemesi ve konut piyasasında fiyata erişilebilirliği destekleyen diğer koşulların bulunması ile ilişkilidir. IKKFS'nin etkinlik kazanmasının ön koşullarının başında ise efektif konut talebini artıracak yeterli satın alma gücü gelmektedir. Diğer bir deyişle konut satın alma talebinin yeterli ve sürekli bir satın alma gücü ile desteklenmesi; İKFS’nin risklerinin azalmasına ve konut sahiplik oranının zaman içinde artmasına katkı sağlayabilmektedir.

Painter ve Redfearn (2001: 18) kısa dönemde faiz oranları ve gelir gibi değişkenlerdeki değişimlerin konut sahipliği oranları üzerinde etkili olmadığını ve konut sahipliğinin zaman içinde (uzun dönemde) değişimini belirleyen en önemli etkenlerin gelir artışı ve demografik değişim olduğunu bulgulamıştır. Sürdürülebilir konut finansmanı için hanehalklarının için yeterli servet birikimine ve gelir akımına sahip olması gereklidir (bkz. Schmitz ve Brett, 2007: 42-43). Servet birikiminin yetersiz olmasi; konut finansmanından faydalanabilmek için gerekli olan ön ödeme tutarının finanse edilememesine ve konut finansmanı risklerinin (kredi kullanıcısı açısından temerrüt riski ve kredi kurumu açısından da kredi riski) artmasına neden olabilmektedir. Konut finansmanı sürecinde yeterli gelire sahip olunamaması da; kredi kullanıcısının konut sahipliğini zaman içinde finanse edememesine, dolayısıyla konut finansmanına bağlı risklerin artmasına neden olabilmektedir. Öte yandan küresel finansal kriz sürecinde de gözlendiği üzere, söz konusu 
risklerin finansal sistemin bütününe sirayet ederek sistemik nitelikler kazanması da olasıdır.

Tablo: 4

Eşdeğer Hanehalkı Kullanılabilir Gelirine Göre Sıralı İlk ve Son Yüzde 20'lik Gruplar (2008-2012)

\begin{tabular}{|c|c|c|c|c|c|c|c|c|c|}
\hline & \multicolumn{3}{|c|}{ İlk \%20\% } & \multicolumn{3}{|c|}{ Son $\% 20$} & \multicolumn{3}{|c|}{ Gini katsayısı } \\
\hline & 2008 & 2010 & 2012 & 2008 & 2010 & 2012 & 2008 & 2010 & 2012 \\
\hline \multicolumn{10}{|l|}{ Türkiye } \\
\hline Yüzde & 5,8 & 5,8 & 5,9 & 46,7 & 46,4 & 46,6 & 0,405 & 0,402 & 0,402 \\
\hline Ortalama (TL) & 2.427 & 2.841 & 3.468 & 19.560 & 22.573 & 27.624 & & & \\
\hline Medyan (TL) & 2.523 & 2.924 & 3.619 & 15.637 & 17.927 & 22.042 & & & \\
\hline \multicolumn{10}{|l|}{ Kent } \\
\hline Yüzde & 6,1 & 6,3 & 6,4 & 46,0 & 45,7 & 46,1 & 0,395 & 0,389 & 0,391 \\
\hline Ortalama (TL) & 2.917 & 3.510 & 4.289 & 21.959 & 25.316 & 31.118 & & & \\
\hline Medyan (TL) & 3.074 & 3.598 & 4.4 .18 & 17.324 & 19.907 & 24.605 & & & \\
\hline \multicolumn{10}{|l|}{ Kur } \\
\hline Yüzde & 6,5 & 6,2 & 6,1 & 44,5 & 44,3 & 44,0 & 0,378 & 0,379 & 0,377 \\
\hline Ortalama (TL) & 1.930 & 2.105 & 2.548 & 13.250 & 14.983 & 18.291 & & & \\
\hline Medyan (TL) & 2.006 & 2.173 & 2.682 & 11.052 & 12.646 & 15.441 & & & \\
\hline
\end{tabular}

Kaynak: TÜIK, (2011: 364).

Konut finansmanına ilişkin sorunların altında yatan nedenler arasında alım gücündeki kısıtların önemli bir payı bulunmaktadır. Ülkemizdeki genel gelir seviyesinin düşüklügü, gelirin bölüşümündeki adaletsizlikler, yüksek işsizlik oranı ve -kırsal kesimde etkisini daha fazla hissettiren- yoksulluk gibi olgular; konut sahipliğini daha da güçleştirmekte, ayrıca konut finansmanına yönelik harcamaların hane halkı gelirindeki nisbi öneminin daha da artmasına neden olmaktadır. Tüm yoksullar Türkiye nüfusuna genellendiğinde hane bazında 2,5 milyon, fert bazında da 10-12 milyondur (bkz. Aydın, 2011: 204). TÜİK verilerine göre hanehalk1 kullanılabilir geliri \%20'lik gruplara bölündügünde son \%20 lik grubun gelirin önemli bir bölümüne sahip olduğu ve söz konusu olgunun kentsel alanda daha çarpıcı bir nitelik kazandığı gözlenmektedir. Aşağıda yer alan çizelgeden de anlaşılacağı üzere, 2012 yılı itibarı ile Türkiye genelinde toplam hane gelirinin yaklaşık \%47 sini en üstte yer alan \%20'lik gelir diliminde bulunan kişiler alırken, en alttaki (yoksul) \%20'lik grup ise gelirin yaklaşık \%6'sını alabilmektedir.

8 Eşdeğer hanehalkı kullanılabilir gelire göre gini katsayısı (Türkiye, Kent, Kır, IBBS, 1. Düzey) ve Eşdeğer hanehalkı kullanılabilir gelire göre sıralı yüzde 20'lik gruplar itibariyle yıllık eşdeğer hanehalkı kullanılabilir gelirin dağılımı (Türkiye, Kent, Kır). Internet: <http://www.tuik.gov.tr/PreTabloArama.do>, (Erişim Tarihi: 18.02.2014). 
Kentsel kesime bakıldığında 2012 yılında, en üstte yer alan \%20'lik gelir diliminde bulunan kişilerin yıllık ortalama geliri 31.118 TL iken, en alttaki (yoksul) \%20'lik grubun yıllık geliri ortalama olarak 4.289 TL'dir. 2012 yılında, kırsal kesimdeki en üst ve en alt gelir gruplarının yıllık ortalama gelir rakamları ise sırasıyla $18.291 \mathrm{TL}$ ve 2.548 TL'dir.

Üçüncü dünya ülkelerine ilişkin güncel yazında kent yaşamının dört temel unsuru; yoksulluk, istihdam, cinsiyetin rolü ve çevre olarak belirlenmiştir (Gilbert, 1994: 605, Aktaran: Erman, 2001: 997). En düşük gelir grubunda bulunan hanehalklarına bütün ülkelerde çeşitli kamusal sübvansiyonlar sunulmaktadır. Ancak GOÜ’nün önemli bir bölümünde nüfusun ağırlıklı kısmı formel konut finansmanına yönelebilecek gelire sahip değildir (Warnock ve Warnock, 2008: 4). Dolayısıyla yoksulluk, konut ve konut finansman sorunları iç içe geçmiş kavramlardır. Ülkemiz bir geçiş ülkesi olarak değil, yüksek orta gelir grubu ülkesi olarak değerlendirilmektedir (bkz. Birleşmiş Milletler, 2010: 66). Bununla birlikte, konut politikalarındaki tutarsızlıklar ve hanehalkının konut finansmanında karşılaştığı gelir/servet yetersizliği sorunları nedeniyle, ülkemiz niteliksel/niceliksel yönleri ve sosyo ekonomik/politik sonuçlarıla konut sorununu uzun yıllardır yaşamaktadır.

Dünya Bankası ve DİE (2005: 12-24) (zaruri yoksulluk yönteminin esas alındığı çalışmalarında), 1994 yılında \%28,3 olan Türk halkının fakirlik oranının makroekonomik istikrarsızlıklar nedeniyle, 2002 yılında ancak \%27 ye inebildiğini, fakirliğin azalmasında ekonomik büyümenin olumlu bir rolünün bulunduğunu belirtmektedir. Aşağıda yer alan TÜIKK verilerine göre de, 2002-2009 döneminde yaşanan büyüme sürecinin yoksul sayısının azalmasına katkı sağladığı görülmektedir. Ancak olumlu gelişmelere karşın, harcama esaslı göreli yoksulluk yöntemine göre, 2009 yılında ülkemizde halen, nüfusun $\% 15$ 'ini oluşturan 10,7 milyon yoksulun bulunduğu tahmin edilmektedir. ${ }^{9}$

Ülkemizde nüfusun ancak \%10’u için uygun ödeme koşullarında konut üretilirken devletin desteğine gereksinim duyan kesimlerin mülk veya kiralık konut edinmeleri için sağlanan herhangi bir katkıdan sözetmek olanaklı değildir. Piyasa koşullarında üretilen konut fiyatları, mevcut gelir dağılımı ve ihtiyaç sahipleri açısından yüksektir. Bu yapıda dar gelirlilerin konut gereksinmesi sorununun devam etmesi olağan görünmektedir (bkz. Bayındırlık ve İskân Bakanlığı, 2009: 28).

92002 yll verileri, 2000-2001 krizi sonrasındaki olağanüstü olumsuz ekonomik dönemi yansitmaktadır. 2009 yllı verileri de, Türk ekonomisinde alışık olunmayan bir ekonomik büyüme/istikrar dönemi sonundaki olumlu durumu içermektedir. Bununla birlikte, ülkemiz ekonomisinde finansal krizlere neden olan yapısal sorunlar ve kirllganlıklar önemli ölçüde varlı̆̆ın korumaktadır. Dolayısıyla, özellikle 2009 yll olmak üzere, her iki yıla ilişkin göstergelerin ihtiyatla yorumlanmasının gerekli olduğu düşünülmektedir. 
Tablo: 5

Yoksulluk Sınırı Yöntemlerine Göre Türkiye'de Yoksul Fert Sayısı ve Yoksulluk Oranları (2002-2009)

\begin{tabular}{|c|c|c|c|c|c|c|}
\hline & \multicolumn{2}{|c|}{2002} & \multicolumn{2}{|c|}{2005} & \multicolumn{2}{|c|}{2009} \\
\hline & Bin Kişi & Oran $(\%)$ & Bin Kişi & Oran $(\%)$ & Bin Kiși & Oran $(\%)$ \\
\hline Gida yoksulluğu (açlık) & 926 & 1,35 & 623 & 0,87 & 339 & 0,48 \\
\hline Yoksulluk (gıda+gıda dışı) & 18.441 & 26,96 & 14.681 & 20,50 & 12.751 & 18,08 \\
\hline Kişi başı günlük 1 \$'ın altı & 136 & 0,20 & 10 & 0,01 & - & \\
\hline Kişi başı günlük 2.15 \$'ın altı & 2.082 & 3,04 & 1.109 & 1,55 & 159 & 0,22 \\
\hline Kişi başı günlük 4.3 \$'ın altı & 20.721 & 30,30 & 11.712 & 16,36 & 3.066 & 4,35 \\
\hline Harcama esaslı göreli yoksulluk & 10.080 & 14,74 & 11.574 & 16,16 & 10.669 & 15,12 \\
\hline
\end{tabular}

Kaynak: TÜIK. ${ }^{I 0}$

Özetle, ülkemizde formel konut piyasasının ve bu bağlamda İKFS'nin gelişememesinin; gelir dağılımının alt/orta gelir grubu aleyhine içerdiği eşitsizliklerle de ilişkisi bulunmaktadır. Konut finansmanında servet/gelir kısıtının ortaya çıkmasında (ve dolayısıyla İKFS'nin yaygın/etkin biçimde gelişememesinde) söz konusu olgunun önemli bir payı bulunmaktadır. ${ }^{11}$ Ülkemizdeki yoksulluk (gelir/servet yetersizliği) yapısı konut sorunu/finansmanı açısından iki önemli sonucun ortaya çıkmasına neden olmuştur. Bunların ilki, gecekondu olgusudur. Diğeri ise, özellikle TOKİ kanalıyla merkezi yönetimin konut sorununun çözümünde (ve konut piyasasının yönlendirilmesinde) önemli bir işlev üstlenmesidir. Aşağıda incelenen söz konusu olgular, ülkemizdeki taşınmaz ekonomisi ve finansal piyasaların gelişme süreçlerini/koşullarını belirlemenin ötesinde, etkisini yakın gelecekte de sürdürecek önemli toplumsal/siyasal gelişmelerin de belirleyicisi konumundadır.

\subsection{Konut Finansmanında Gelir/Servet Yetersizliğinin Sonuçları}

\subsubsection{Konut Finansmanında Gelir/Servet Yetersizliği ve Gecekondu Olgusu}

Nitelikli konut sorununun hangi boyutlarda olduğunu yansıtan sosyo-ekonomik bir ölçüt olarak gecekondu sorunu, doğası gereği, İKFS'nin ve formel konut finansmanının gelişimini olumsuz yönde etkilemektedir. Konuya ilişkin yazında kapsamlı biçimde

10 Internet: <http://www.tuik.gov.tr/VeriBilgi.do?tb_id=23\&ust_id=7>, (Erişim Tarihi: 16.05.2012).

11 Bununla birlikte Hoek-Smit (2009: 422) formel konut piyasasının az gelişmiş olmasının sadece düşük gelirle ilişkili olmayabileceğini belirtmektedir.Bu bağlamda kayıt dişı istihdam nedeniyle finans sistemine erişimin olmaması, tasarruf/servet yetersizliği, arazi yönetimi ve kadastro sistemindeki yetersizlikler nedeniyle teminatta belirsizlik yaşanması, farklı taşınmazlar üzerinde farklı hakların bulunması veya komşuluk risk etkenleri, konut finansmanı piyasalarının etkin/tamam olmaması ve piyasada yeterli konut finansmanı ürününün bulunmaması gibi hususlar da formel piyasanın gelişmesini olumsuz yönde etkileyebilmektedir. 
incelenen ülkemizdeki gecekondu yerleşiminin önemli nedenlerinden birisi de, barınma gereksiniminin nitelikli konutlarda giderilememesine neden olan gelir/servet yetersizliğidir. $^{12}$

Ülkemizde yerleşmeler; imara aykırı ve kaçak yerleşmeler ve imara uygun planlı yerleşmeler biçiminde olmaktadır. İmara aykırı ve kaçak yerleşmeler; özellikle kamu arazileri üzerinde, başlangıçta büyük nüfus hareketlerinin ve kırdan kente göçün yarattığ1 ekonomik ve sosyolojik nedenlerle başlamış olup; masum görünüşlü, barınma amaçlı, tek katlı ve genelde kentin dış çevrelerinde oluşan; plansız, ruhsatsız, yasalara aykırı yerleşimler olarak ortaya çıkmıştır. İmara uygun planlı yerleşmelerde ise; 3194 sayılı İmar Kanunu'nun arazi ve arsa düzenlemesi başlıklı 18 inci maddesi ve ilgili yönetmelik uygulanmaktadır (Ülger, 2004: 57).

Ülkemizdeki temel konut üretim biçimlerinin başında; küçük/büyük ölçekli özel sektör kişi/kurumları tarafından formel piyasa mekanizması kapsamında gerçekleştirilen konut üretimi gelmektedir. İkinci olarak, gecekondu sisteminin informel piyasa mekanizmasına dayalı bir üretim biçimi olarak önemli bir konut stokunu oluşturduğu görülmektedir. ${ }^{13}$ Son olarak, son yıllarda önemi giderek artan ve ağırlıklı olarak sosyal konut arzı sağlayan, TOKİ ve belediyelerin konut üretimleri de önemli bir konut üretim/finansman modeli olarak dikkat çekmektedir. Gecekondu sayısına ilişkin resmi bir veri bulunmamakla birlikte, ${ }^{14}$ tahmini stok büyüklükler dikkate alındığında, gecekondu üretim/finansman biçiminin ülkemizdeki temel konut üretim/finansman formlarının başında geldiğini söylemek mümkündür. $\mathrm{Bu}$ nedenle sadece sayısal açıdan değerlendirildiğinde bile; gecekondu sorunu aynı zamanda konut sorununun en önemli göstergelerinden biri olarak kabul edilebilir.

12 Günümüzde mülkiyet sorunları çözülen gecekonduların yerine yapılan yapılar kentsel rantın yaratılmasında etkili olmakta, bu süreçte konut üreticisi/tüketicisi kredi kullanımı yoluyla finans sistemine eklemlenebilmektedir. Ancak söz konusu olgunun alt/orta gelir grubunun konut sorununun çözülmesindeki etkinliği ve finansal sistemin gelişmesine katkısının yeterince güçlü olmayabileceği söylenebilir. Bununla birlikte, ülkemizdeki iç göç olgusu ve yoksulluk verileri birlikte değerlendirildiğinde, önümüzdeki dönemde de gecekondu yapısının sosyo-ekonomik/politik etkilerinin süregeleceğini öngörmek mümkündür.

13 Erder (2007: 275) imarlı olsun ya da olmasın, gecekondu da dâhil olmak üzere, hemen bütün konutların artık piyasa için üretildiğinin altını çizmektedir.

14 Veri üretimi kapsamında ülkemizden oldukça farklı bir tablo çizdiği görülen Malezya'nın resmi verilere göre 1999 yılındaki gecekondu sayısının 571.261 “adet” olduğu belirtilmektedir (Shuid, 2010: 10). 


\section{Şekil: 1 \\ Türkiye'deki Temel Konut Üretim ve Finansman Biçimleri}

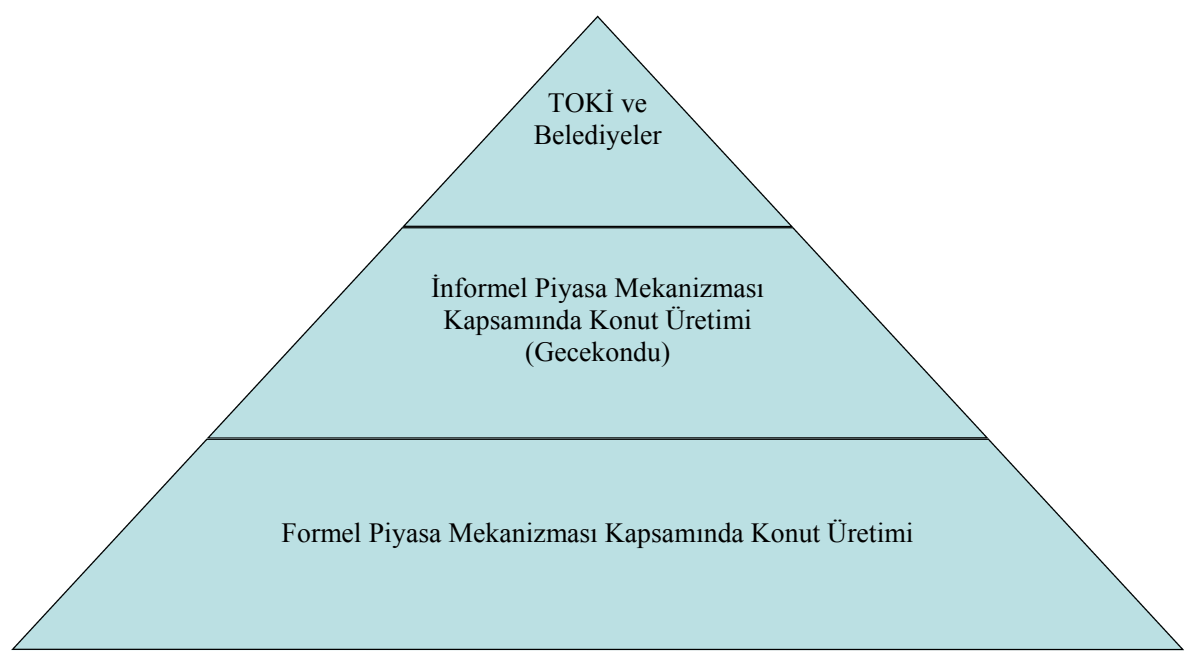

Kaynak: Coşkun (2013a).

Gecekondu yerleşimine ilişkin bütün unsurları yansıtamamakla birlikte gecekondu; rahat (nitelikli) bir yerleşim olmayan ve bir gecede hazine, belediye veya bireylerin sahip olduğu araziye imar hukuku ve mülkiyet haklarına aykırı olarak yapılan yapı olarak tanımlanabilir (Karpat, 2004: 10). İç göç, kentleşme, gelir/birikim kısıtt, hukuksuzluk ve maddi/siyasi rant ekseninde gelişen gecekondu olgusunun; konut gereksinimi, politikaları ve finansmanı ile doğrudan ilgisi bulunmaktadır.

Diğer konut finansman kaynaklarındaki sınırlamaların bir sonucu olarak, yoksul kesimin konut finansmanında en fazla kullandığı araç gayri resmi (informal) sistemler olmaktadır (Schmidt ve Budinich, 2006). Konut sorununun çözümünde ülkemizin nerede bulunduğunu gösteren olguların başında, Çiloğlu (1998: 86) de kayıt dışı ve Bilgin (2002) de enformel konut üretimi olarak adlandırılan, gecekondu sorunu/olgusu gelmektedir. Gecekondu olgusu nitelikli konut sorununun hangi boyutlarda olduğunu yansıtan önemli bir sosyo-ekonomik göstergedir. De Soto (2000: 53) gecekonduların ülkemiz nüfusunun en az yarısının barınma gereksinimini karşıladığını belirtirken, Türk ve Altes (2010: 30) de kentsel nüfusun \%29 unu oluşturan 12,5 milyon kişinin 2,5 milyon gecekonduda yaşadığının altını çizmektedir. 
Ülkemizde modern konut finansman tekniklerine dayalı konut edinimi, ekonomik/sosyal/siyasal nedenlerle toplumun tüm kesimlerine yaygın değildir. Dolayısıyla, gecekondudaki konut edinme sistemi; üretim ve finansman biçimleri, hukuksal süreçler ve mülkiyet ilişkileri gibi konularda formel konut edinme sisteminin dışında kalmaktadır. Tekeli (1982: 209), gecekondu üretiminin konut miktarından bağımsız olduğunu, var olan konut sunum biçimlerinin gecekondularda oturan gruplara sunum yapamadığını ve ülkedeki konut gereksinmesinin tamamının karşılanması için yeterli yatırım yapılsa bile mevcut sunum sistemleri ve piyasa mekanizması içinde gecekondunun varlığının ortadan kaldırılamayacağını belirtmektedir.

Ülkemizde gecekondulaşmanın önüne geçilmesine yönelik olarak 5237 sayılı Türk Ceza Kanunu'nun 181 ve 184 üncü maddelerinde engelleyici hükümler bulunmaktadır. TOKİ ise gecekondulaşmanın önüne geçilmesinde görev verilen kurumlar arasında başta gelmektedir (Bayraktar, 2007: 20-23). Ancak ülkemizdeki gecekondu sorunu bütün ağırlığı ile varlığını sürdürmektedir. Kanımızca gecekondu sorununa yönelik uzun vadeli ve kalıcı çözüm; sanayileşme, kırsal istihdamın artması gibi makro iyileşmeler ve arsa rantı değil; sosyal amaçları ön plana çıkaran arazi/yerleşim/konut politikaları ile ilişkilidir. Bu bağlamda söz konusu süreçte iyi tasarlanmış kentsel dönüşüm projelerinin ve modern taşınmaz finansı tekniklerinin ön plana çıkmasının; konut sorununun çözülmesine ve taşınmaz piyasasının etkin/kurallı/istikrarlı biçimde gelişmesine katkı sağlayabileceği düşünülmektedir.

İnceleme konumuz açısından değerlendirildiğinde ise; gecekondu olgusunda içselleşen hanehalkının gelir/servet yetersizliği, aynı zamanda formel konut piyasası ve söz konusu altyapı çerçevesinde gelişmesi beklenen İKFS için de dikkat çekici bir sınıra işaret etmektedir. Söz konusu sorunun önemli bir sonucu ise; merkezi yönetimin TOKİ kanalıyla konut piyasası ve bu piyasa ile ilişkili diğer piyasalara doğrudan ve dolaylı müdahaleleridir.

\subsubsection{Konut Finansmanında Gelir/Servet Yetersizliği ve TOKİ Sistemi}

Devlet konut piyasasına doğrudan/dolaylı biçimde üretici olarak veya diğer yollarla müdahale etmektedir. Bunun altında yatan ilk neden, özellikle alt/orta gelir grubundaki hanehalklarının konuta yönelik giderlerinin ve konut finansmanı maliyetlerinin yüksek olmasıdır. İkinci neden ise, konut piyasasının canlı olmasının toplum refahını artırmasıdır. ${ }^{15} \mathrm{Bu}$ kapsamda konut piyasasına yönelik kamu müdahalesinin başlıca amaçları; ortalama konut fiyatının düşürülmesi, piyasa mekanizması tarafından üretilen 15 Kanımızca konut piyasasına yönelik kamu müdahalesinin bir diğer nedeni de; konut piyasasına sağlanan
teşvik ve sübvansiyonların gelir adaletsizliği ve bölüş̧üm sorunlarının azalmasına katkı sağlamasıdır. 
konutların yoksul hane halkı açısından fiyat erişilebilir olması ve (konut fiyatlarının düşürülmesi çerçevesinde) tüketimin artırılması olarak belirlenebilir (Whitehead, 2007: 30).

Ülkemizde 1980 sonrasında TOKİ'nin faaliyetleri çerçevesinde ivme kazanan alt/orta gelir grubuna yönelik fiyat erişilebilir konut arzı hala süregelmekle birlikte, esas itibarı ile özel sektör konut üretiminin teşvik edilmesi düşüncesinin ön plana tutulduğunu belirtmek gereklidir. Temel amacı konut finansmanı bağlamında, başta sermaye piyasaları olmak üzere, finansal piyasaların düzenlenmesi olan, 5582 sayılı Kanun'un da konut finansmanında özel sektörü ön plana çıkaran bir yaklaşıma sahip olduğu söylenebilir. Bununla birlikte TOKİ'nin son yıllarda hızla gelişen faaliyetleri dikkat çekici görünmektedir.

TOKI'nin kuruluş dönemi sonrasındaki faaliyetlerini inceleyen Fannie Mae; 1984 yılındaki kuruluşu sonrasında TOKİ'nin ülkemizdeki konut kredisi finansmanının en önemli kaynağı haline geldiğini belirtmektedir. 1984-1990 döneminde 258.588 adet ipotekli konut kredisi Emlak Bank, Vakıfbank ve Pamukbank aracılığıla kullandırılmıştır. Söz konusu dönemde önemli ölçüde sübvanse edilen TOKİ kredilerindeki borç değer oranı \%20 veya daha düşük bir seviyede bulunmaktaydı (Fannie Mae, 1992: 2, 11, 14). TOKİ; hem doğrudan konut üretmiş, hem de kooperatiflere, toplu konut yapımcılarına kredi açarak konut üretimine katkıda bulunmuştur (Kongar, 2003: 560). TOKİ, bir defaya mahsus olmak üzere konut kredisi kullandırmakta, ancak ferdi konut kredisi kullandırmamaktadır (TOKI, 2010b: 65). Bayraktar (2008: 11; 2009: 26; 2010: 17) bir şemsiye kurum olarak nitelediği ve özel sektör (müteahhitler) aracıllı̆̆ ile faaliyetlerini yürüten TOKI'nin devlete daha fazla kaynak sağlamanın yanı sıra; piyasayı disipline etme ve fiyatları aşağıya çekmeyi de amaçladığını belirtmektedir. Kredilendirme, konut ve işyeri üretimi/satışı, arsa üretimi/satışı, sigorta ve kısmen imar planı yapabilme gibi geniş yetkilerle teçhiz edilen TOKİ ülkemizdeki konut üretiminde önemli bir yere sahiptir. Kamu kaynaklarını kullanmadığı ifade edilen ${ }^{16}$ (bkz. Üçışı, 2006: 56) Kurum ayrıca faaliyetleri kapsamında çeşitli şirketlerin sermayelerine de iştirak etmektedir (bkz. TOKİ, 2010a: 152; Hazine Müsteşarlığı, 2010: 182).

16 Varlık fiyatlarının yüksek olduğu ve dış kaynak finansmanına dayall olsa da ekonomik büyümenin sürdürülebildiği bir konjonktürde TOKI'nin finansman sistemi kisa vadede sürdürülebilir görünmektedir. Bununla birlikte, TOKİnin kamuya açıkladığ son derece kisıtll finansal bilgilerden Kurum'un kamu kaynaklarını hangi biçimde ve verimlilikte kullandı̆̆ geniş anlamda Kurum'un fayda-maliyet analizi bağımsız araştırmacılar tarafindan objektif olarak yapılamamaktadır. Söz konusu analizin fayda kısmının salt üretilen konut sayısına indirgenmesi de yeterince açılayıcı değildir. Kanımızca kamu kaynaklarının kullanımındaki etkinliğin taşınmaz varlıkları da içerecek şekilde ele alınması ve TOKİnin performansının kamu taşınmazlarını sosyal yararı da dikkate alarak ne ölçüde verimli kullanabildiğinin belirlenerek ölçülmesi gereklidir. 
Aşağıda yer alan tablodan da anlaşılacağı üzere, TOKİ'nin alt/dar/orta gelir grubu ve yoksul olarak nitelediği kesimleri de içeren sosyal konut üretimi 200318.02.2014 dönemindeki toplam konut üretiminin \%86'sını oluşturmaktadır. Dolayısıyla, TOKI'nin konut üretimine yönelik faaliyetlerinin temel amaçlarının başında; gelir/servet kısıtı nedeniyle piyasa mekanizmasına dayalı olarak konut sahibi olması mümkün olmayan gelir gruplarına uygun koşullarda konut sağlanmasının geldiği söylenebilir.

\section{TOKI'nin Sosyal Konut Üretimi (2003-18.02.2014)}

\begin{tabular}{|c|c|c|}
\hline Sosyal Konut Türü/Konut Üretim Biçimi & $\begin{array}{l}\text { Üretim } \\
\text { Adedi }\end{array}$ & $\begin{array}{c}\text { Sosyal Konut Üretimindeki } \\
\text { Payı (\%) }\end{array}$ \\
\hline Dar ve Orta Gelir Grubuna Yönelik Konutlar & 245.193 & 40,49 \\
\hline Alt Gelir Grubu ve Yoksullara Yönelik Konutlar & 144.835 & 23,92 \\
\hline Gecekondu Dönüşüm & 88.236 & 14,57 \\
\hline Afet Konutu Uygulaması & 37.688 & 6,22 \\
\hline Tarımköy Uygulamaları & 5.584 & 0,92 \\
\hline Toplam Sosyal Konut & 521.536 & 86,12 \\
\hline Kaynak Geliştirme (TOKİ) & 22.974 & 3,79 \\
\hline Kay. Gel. (EGYO+EPPY) & 64.384 & 10,64 \\
\hline Toplam Kaynak Geliştirme & 87.358 & 14,43 \\
\hline TOPLAM & 608.894 & 100,00 \\
\hline
\end{tabular}

Kaynak: TOKI Konut Üretim Raporu. ${ }^{17}$

TOKİnin son yıllarda gerçekleştirdiği atılımın özellikle sosyal konut üretiminde önemli bir sıçramaya neden olduğu açıktır. Bu kapsamda, TOKİ faaliyetlerinin konut sorununda sosyal devlet ilkesinin hayata geçirilmesi açısından önem taşıdığı görülmektedir. Bununla birlikte TOKI'nin uyguladığı finansman sisteminin çeşitli açılardan eleştiriye açık olduğunu da belirtmek gereklidir. İlk olarak, TOKİnin finansal bilgilerinin kamuya açılanmaması kurum faaliyetlerini şeffaflıktan uzaklaştırmaktadır. $\mathrm{Bu}$ bağlamda sübvansiyon tutarına, proje bazında gelir/gider/karlılık verilerine ve bilanço kalemlerine ilişkin ayrıntılı verilere ulaşılamamaktadır. TOKİ faaliyetlerinin önemli ölçüde kamu denetiminin dışında kaldığ $1^{18}$ dikkate alındığında, şeffaflıktan uzak yapının hesap

17 Internet: <https://www.toki.gov.tr>, (Faaliyet Özeti İkonu, Erişim Tarihi: 18.02.2014).

18 TOKI'nin hesapları Sayıştay tarafindan denetlenmektedir (bkz. Sayıştay Başkanlığı, 2013). 1164 sayılı Arsa Üretimi ve Değerlendirilmesi Hakkında Kanun'un 6 nct maddesinde; TOK亡̇'nin arsa alımı ve satımı, harita, planlama, kamu tesis ve hizmetlerinin yapılmasl ve diğer döner sermaye işlemlerinin 1050 sayll Muhasebe-i Umumiye Kanunu (5018 sayıl Kamu Mali Yönetimi ve Kontrol Kanunu) ile 2886 sayll Devlet Ihale Kanunu'na tabi olmadığ belirlenmiştir.TOKI (2010a: 158) da, Kurum ile iş yapan yüklenici firmaların seçilmesinin Kamu İhale Kanunu'na tabi olduğu ve konut üretimi sürecindeki risklere karşı Kurum'un korunduğu belirtilmektedir. Konuya ilişkin yazında TOKI'ye yönelik denetim sisteminin etkin olmayabileceğine ilişkin görüşler bulunmaktadır. Bu bağlamda Keleş (2010: 6) TOKİ'nin denetimden kaçınması için Kamu İhale Kanunu'nun dışına çıkarıldığını belirtirken, Geray (2010: 9) da denetimsiz olan Kurum'un serbest hareket ettiğini belirtmektedir. 
verebilirlik açısından sorunlara neden olabileceği düşünülmektedir. İkinci olarak TOKİ'nin doğrudan/dolaylı olarak üretici bir kurum olması, kamu ekonomisinin büyümesine neden olmakta ve özel sektöre dayalı girişimciliği olumsuz yönde etkileyebilmektedir (Coşkun, 2011c: 24).

Üçüncü olarak, TOKİ'nin temel finansman kaynağının proje gelirlerine ve krediye (doğrudan finansmana) dayalı olmasının ve menkulleştirme aracının çeşitli nedenlerle aktif olarak kullanılamamasının finansman yapısı açısından olumsuzluğa neden olabileceği değerlendirilebilir. Ayan (2011: 140, 148, 152) TOKİ'nin yüklenicilere olan ödemelerinin 2 yıla, konut satışı gelirlerinin ise 8-12 yıla yayılmasının Kurum'da ve birçok küçük/orta ölçekli yüklenici inşaat şirketinde finansal sorunlara neden olduğunu belirtmektedir. Söz konusu çalışmada ayrıca, TOKİnin likidite sorunları karşısında Hazine arazisi satması kaynak israfı olarak nitelendirilmekte ve yasal açıdan menkul kıymet ihracı konusunda bir engeli bulunmayan Kurum'un kamu kaynaklarına dayalı finansman yaklaşımını sürdürmesinin ülkemizdeki modern konut finansmanının işlerlik kazanmasına engel olduğu vurgulanmaktadır.

TOKİ'nin atılım yaptığı 1990 sonrası dönemde toplu konut fonu uygulamasının sürdürülememesinin altında kaynakların giderek yetersiz hale gelmesinin önemli bir payı bulunmaktadır. Günümüzde TOKİ'nin kaynaklarının önemli bir kısmını girişimci gibi bulmaya zorlanmasının, kentsel alandaki kamu taşınmazlarına yönelik uzun vadeli bir stratejinin olmamasının ve söz konusu varlıkların satılmasının, menkul kıymet ihracı gibi modern konut finansman teknikleri kullanılmaksızın kaynak yaratılmaya çalışılmasının; konut sorunu gibi devasa ve sürekliliği bulunan bir sorunun sürdürülebilir koşullarda çözülmesi için yetersiz bir çerçeve sunduğu düşünülmektedir. ${ }^{19}$

TOKİ sisteminin son yıllarda hızla büyümesinin nedenleri arasında, konut talep eden hanehalklarının gelir/servet yetersizliği sorununun kamusal girişimler yoluyla çözümlenmek istenmesi de bulunmaktadır. Bununla birlikte, yukarıda yer verilen -ve daha da genişletilebilecek- eleştiriler, TOKİ sisteminin önemli riskler içerebileceğinin ve uzun vadede sürdürülebilirliğinin tartı̧̧ma konusu edilebileceğinin altını çizmektedir. Bu bağlamda, TOKİ ve sosyal politikalar ekseninde geliştirilecek optimal bir teşvik sisteminin; konut finansmanında gelir/servet yetersizliğine dayalı (gecekondu olgusundan/TOKI'den kaynaklanan) sorunların asgariye indirilmesinde etkili olabileceği, dolayısıyla TOKİ sisteminden kaynaklanabilecek risklerin de azalmasina katk1 sağlayabileceği düşünülmektedir.

19 TOKÍnin menkulleştirmeye dayalı kaynak sağlayamamasının nedenleri farklı bir incelemenin konusu olmakla birlikte, yeterli düzenleme altyapısına karşın, menkulleştirmenin yapılmasını kolaylaştıracak piyasa dinamiklerinin ve kurumsal yapının ülkemizde yeterince gelişmediğini de belirtmekte fayda vardır. 


\section{Konut Finansmanında Gelir/Servet Yetersizliği İçin Bir Çözüm Önerisi: Optimal Teşvik Sistemi Tasarımı}

\section{1. İKFS'ne Yönelik Teşvik Önerileri}

IKFS'nin etkinlik kazanamamasının temel nedenlerinin başında gelen gelir/servet yetersizliği sorununun çözümüne yönelik olarak 5582 sayılı Kanun'da hiç bir düzenlemeye yer verilmemesi dikkat çekicidir. Sözkonusu yaklaşım, 5582 sayılı Kanun'un ve İKFS'nin uzun dönemde etkin bir başarı elde edemeyecek olmasının temel nedenlerinden birini oluşturmaktadır. ${ }^{20}$ Konut sorununun asgariye indirilmesi sürecinde İKFS'nin katkısının artırılması çok sayıda ön koşulun varlığını gerektirmektedir. $\mathrm{Bu}$ süreçte, diğer ön koşullar veri iken, optimal teşvik sistemlerinin uygulamaya konulması çerçevesinde gelir/servet yetersizliğinin olumsuz etkilerinin asgariye indirilmesinin İKFS'yi geliştirilebileceği (ve dolayısıyla konut sorununun kısmen çözülmesine katkı sağlayabileceği) düşünülmektedir.

Konut finansmanında diğer şartların önemi veri olmakla birlikte, özellikle GOÜ'deki koşulların devletin konut finansmanındaki rolünü daha da artırdığını belirtmek gereklidir. Bu kapsamda Konut Müsteşarlığı (2003: 19), konut sahibi olmayan kesimin konut edinebilmesi için piyasa mekanizmasının dışında devlet müdahalesi gerektiren politikaların takip edilmesi gerektiğinin altını çizmektedir. DPT (2001: 60), sekizinci beş yıllık kalkınma planı konut özel ihtisas komisyonu raporunda; gelişmiş ve gelişmekte olan ülke deneyimleri kapsamında dar gelirlinin konut edinmesinin, büyük ölçüde kamu sübvansiyonlarıyla gerçekleşebileceğini belirterek, dar gelirli kesimin konut ihtiyacının karşılanmasının ayrı bir programla ve çok sübvansiyonlu bir yapı içinde olması gerektiğini belirtmektedir.

Alt/orta gelir grubunun İKFS kapsamında fiyata erişebilirliğini geliştirebilecek başlıca teşvik türleri; ipotek kredisi faiz giderlerinin vergiden indirilmesi, düşük gelirli hane halkının ipotek kredilerinin sübvanse edilmesi, ilk defa konut alacakların ön ödeme tutarına yönelik sübvansiyon sağlanması, ilk defa konut alacaklara yönelik hibe sağlanması ve diğer yardımlarda bulunulması, düşük faizli ipotek kredilerine dayalı veya alt/orta gelir gruplarının finansmanına yönelik ipoteğe dayalı menkul kıymetlerin faiz gelirlerine vergi indirimi sağlanması ve düşük gelirli hane halklarının kira veya ipotek kredisi ödemelerine

Son yıllarda ülkemizdeki konut kredileri hacmindeki artış oransal olarak dikkat çekici olmakla birlikte, büyümenin azalarak artan ve dură̆anlaşma eğilimi gösteren bir yapısı bulunmaktadır. IKFS'nin gelişme koşullarını da olumlu yönde etkileyen son dönemdeki makroekonomik performansa karşın, konut kredileri hacmi/GSYIH oranı \%5-6 seviyelerinde istikrar kazanmış gibi görünmektedir. Bu durum IKFS'deki gelişmenin anahtarının, hane halklarının önemli bir bölümünün konut gereksinimini efektif bir talep olmaktan çıkaran, gelir/servet kısıtının giderilmesine yönelik politikalar olabileceğini düşündürmektedir (Yalçıner ve Coşkun, 2014). 
devlet garantisi sağlanması olarak belirlenebilir. Öte yandan, İKFS dışındaki konut finansman sistemlerinin desteklenmesinin konut (finansman) sorununun çözümünü olumlu yönde etkileyebileceğini de belirtmek gereklidir.

$\mathrm{Bu}$ kapsamda, konut sorununa çok yönlü çözümler üretilmesi amaciyla hayata geçirilmesini önerdiğimiz TOKİBANK' $n^{21}$ destekleyebileceği tamamlayıc1 konut finansman sistemleri arasında; konut sandı $\breve{g} 1 /$ konut yapı kooperatifi/mikro kredi/sözleşmeye dayalı tasarruf sistemi uygulamalarının ve yerel yönetimlerin fiyat erişilebilir konut üretimi faaliyetlerinin de bulunabileceği düşünülmektedir. Söz konusu tamamlayıcı konut finansmanı sistemleri arasında sözleşmeye dayalı tasarruf sisteminin konumu dikkat çekici görünmektedir. Bu çerçevede, İKFS'ye yönelik dolaylı bir teşvik sistemi olarak da görülebilecek, konut tasarruf planlarına vergisel avantajlar sağlanması, konut alımı amaçlı tasarruflara sübvansiyon sağlanması ve konut sandıklarından konut alımı amaçlı erken nakit çekişlerine olanak sağlanması önerilerini de dikkate alarak sözleşme sistemine dayalı konut finansmanının desteklenmesi mümkündür (bkz. Whitehead ve Scanlon 2002).

Genel olarak yukarıda yer verilen politikaların, alt/orta gelir gruplarının konut sorununu çözmeye yönelmesinin; ülkemizdeki konut (finansmanı) sorununun sürdürülebilir bir finansman çerçevesi içinde asgariye indirilmesinde etkili olabileceği düşünülmektedir. Söz konusu teşviklerin uygulanmasında konut politikaları ve sosyal politikalar çerçevesinde belli sosyal grupların öncelikli olarak hedeflenmesinin teşvik sisteminin özgül bir amaca ulaşmasını da sağlayabileceği düşünülmektedir. Bu bağlamda, ilk defa konut alacak düşük gelir grubuna mensup ailelerin ve muhtaç sosyal kesimlerin IKFS'ye ilişkin (ve diğer) teşvik sistemleri çerçevesinde desteklenmesine öncelik verilmesi mümkündür.

\subsection{Teşviklerin Finansmanı}

İKFS'de alt/orta gelir gruplarına yönelik fiyat erişilebilir konut finansmanı ürünlerinin sunulabilmesi için İKFS'nin teşvik sistemleri ile desteklenmesi bir gereklilik olarak ortaya çıkmaktadır. Ancak bu süreçteki en önemli sorun teşviklerin önemli bir kamusal finansman gerektirmesidir. Aşağıdaki tablodan da anlaşılacağı üzere, 2004 yılı itibarı ile konuta yönelik kamusal harcamaların ulusal bütçe ve GSYİH içindeki payı sirasiyla Polonya'da \%1,2 ve \%0,2; Macaristan'da \%1,9 ve \%0,9; Romanya'da ise \%7,2 ve $\% 2,3$ olarak gerçekleşmiş̧ir.

21 Söz konusu çözüm önerilerine yönelik kapsamlı bir tartışma için bkz. Coşkun (2013a). 
Tablo: 7

\section{Çeşitli Ülkelerde Konuta Yönelik Kamusal Harcamalar (2004)}

\begin{tabular}{|l|c|c|c|c|c|c|c|}
\hline Ülke* & PL & HU & CZ & SK & EE & RO & UA \\
\hline UBP (\%) & 1,2 & 1,9 & 2,3 & 2,8 & 0,1 & 7,2 & 1,3 \\
\hline GSYİHP(\%) & 0,2 & 0,9 & 0,7 & v/y & v/y & 2,3 & 0,3 \\
\hline
\end{tabular}

Kısaltmalar: UBP; konuta yönelik kamusal harcamaların ulusal bütçedeki payı. GSYİHP; konuta yönelik kamusal harcamaların GSYİH'daki payı. v/y; veri yok *Çek Cumhuriyeti ve Litvanya'nın verileri 2003 yılına diğerleri ise 2004 yılına aittir. Ülke adı kısaltmaları; PL: Polonya, HU: Macaristan, CZ: Çek Cumhuriyeti, SK: Slovakya, EE: Estonya, RO: Romanya, UA: Ukrayna.

Kaynak: Shinozaki (2005: 43).

McKinsey Global Institute (2003: 312); ülkemiz İKFS'nde uygulanabilecek teşviklerin büyüklüğünün ipotekli konut kredileri hacminin \%4 ü kadar olabileceğini belirtmekle birlikte; konut sorununun çözülmesine ve bunun özelinde İKFS'nin geliştirilmesine yönelik teşvik sistemlerinin olası maliyetlerine ilişkin olarak ilgili yazında kapsamlı bir çalışmanın bulunmadığı görülmektedir. IKFS kapsamında geliştirilmesini önerdiğimiz teşvik sistemlerinin olumlu/olumsuz yönlerinin ve maliyetlerinin Çevre ve Şehircilik Bakanlığı ve TÜIK'in önderlik edebileceği bir çalışma sonucunda belirlenebileceği ve bu kapsamda optimal teşvik sistemi önerisinin kapsamlı bir tartışmanın konusu olabileceği düşünülmektedir.

\section{Sonuç}

Konut sorunu, ülkemizin karmaşı sosyo-ekonomik/politik sorunlarının başında gelmektedir. Konut sorununun asgariye indirilmesi birçok ön koşulun varlığını gerektirmektedir. Bu kapsamda son yıllarda ülkemizde ipotekli konut finansman sisteminin (IKFS) konut sorununun çözülmesinde seçenek oluşturabileceği gündeme getirilmiştir. Alt/orta gelir grubunun konut sahipliğinin geliştirilmesini öngören sosyal politikalar bağlamında yeniden tasarlanması durumunda, İKFS konut sorununun asgariye indirilmesine katkı sağlayabilir. İKFS'nin gelişmesi ayrıca taşınmaz-finans piyasaları arasındaki bağı güçlendirerek konut ve finans piyasalarının gelişmesini olumlu yönde etkileyebilmektedir. Söz konusu olgu 1970'ler sonrasında ABD sermaye piyasalarında gözlenen olumlu gelişmelerin nedenleri arasında yer almaktadır. Konut politikası bağlamında; İKFS'nin temel amacı özellikle alt/orta gelir grubunun konut (finansmanı) sorununun çözülmesinin kolaylaştırılması olarak belirlenebilir. Bu kapsamda İKFS'nin başarım düzeyi üzerinde, birbiri ile ilişkili olduğu görünen, sistemin tamamlanmışlık derecesi ve fiyat erişilebilir ürünler sunabilme kapasitesinin geliştirilmesi etkili olmaktadır.

Diğer sorunların yanı sıra, istihdam/bölüşüm sorunları nedeniyle ülkemizdeki alt/orta gelir gruplarının gelir seviyesinin/servet birikiminin yetersiz olması, söz konusu grupların konut finansmanında kredi mekanizmasına yaygın olarak yönelememesine neden olmaktadır. Söz konusu olgu; konutta fiyata erişebilirliğin (dolayısıyla İKFS'nin 
tamamlanmışlık derecesinin) azalmasına ve İKFS'nin kitlesel ölçekte etkin bir uygulamaya dönüşememesine neden olmaktadır. Konut finansmanında gelir/servet yetersizliği sorunu gecekondu olgusunun zaman içinde kronik bir hal almasına neden olmuştur. Konut sorununa çözüm üretilmesi amacıyla TOKİ sisteminin şeffaf performans ölçütleri dışında büyümesi de diğer önemli bir sorun olarak göze çarpmaktadır.

Literatür taraması ve karşılaştırmalı veri analizi çerçevesinde yapılan çalışmamızın kapsamını; İKFS'nin gelişmesinin ve konut sorununun asgariye indirilmesinin önündeki kısıtların başında gelen gelir/servet yetersizliği sorununun kapsamı ve bu sorundan kaynaklanan başlıca olumsuzlukların İKFS'nin gelişimi üzerindeki etkisi oluşturmaktadır. İnceleme kapsamında özellikle gelir dağılımı, yoksulluk ve gecekondu olgusu bağlamında informel konut finansmanı ile İKFS'nin gelişme koşulları arasındaki ilişki de incelenmiştir. Araştırma sonucunda, ilk olarak, konut talep edenlerin karşılaştığ 1 gelir/servet yetersizliği sorununun ve bunun da etkisiyle gelişen gecekondu sorununun İKFS'nin gelişmesi önündeki önemli sosyo-ekonomik sınırların başında geldiği belirlenmiştir. Dolayısıyla gecekondu ekonomisinin ve yoksulluğun egemen olduğu bir sosyo-ekonomik yapıda; kredi alma/geri ödeme kapasitesi olan gelir grubuna yönelik olduğu gözlenen İKFS'nin, alt/orta gelir grubunu da kapsayacak şekilde, gelişme göstererek ölçek ekonomisi yaratmasının güç olduğu söylenebilir. İkinci olarak, son yıllarda hızla büyüyen TOKİ sisteminin, konut finansmanında gelir/servet yetersizliğinin konut sorunu üzerindeki olumsuz etkisinin azaltılması amacıyla ivme kazandığı, ancak önemli riskleri de içerebileceği belirlenmiştir.

Bu kapsamda, gelir/servet yetersizliği ve bundan kaynaklanan gecekondu olgusu ve TOKİ risklerine yönelik bir çözüm önerisi olarak, konut finansmanına yönelik optimal bir teşvik sistemi tasarımının gündeme gelebileceği düşünülmektedir. Konut sahipliğinin artırılmasını amaçlayan İKFS'nin gelişimi için, gerekli ön koşulların oluşturulması sürecinde teşvik mekanizmalarının kullanılabileceği ve alt/orta gelir gruplarının İKFS yoluyla konut sahipliğini destekleyecek konut politikalarının konut sorununun çözümlenmesinde etkili olabileceği düşünülmektedir.

Bu noktada çalışmamızın kapsamı dışında kalmakla birlikte gelecekte yapılacak araştırmalara katkı sağlayabileceğini düşündüğümüz iki önerinin daha altını çizmek isteriz. İlk olarak, IKFS kapsamında geliştirilmesi önerilen teşvik sistemlerinin olumlu/olumsuz yönlerinin ve maliyetlerinin, Çevre ve Şehircilik Bakanlı̆̆ı ve TÜİK'in önderlik edebileceği bir çalışmanın sonucunda, belirlenerek optimal teşvik sistemi önerisinin kapsamlı bir tartışmanın konusu olabileceği düşünülmektedir. İkinci olarak, TOKİ'nin konut finansmanını destekleyen finansal bir kuruma dönüştürülmesinin sağlayabileceği konut sahipliğinin artması ve IKFS'nin gelişmesi gibi faydaların daha ayrıntılı olarak inceleme konusu edilebileceği düşünülmektedir. 


\section{Kaynakça}

Ayan, E. (2011), “Konut Finansmanı Sistemi ve Türkiye'de TOKİ Uygulamalarının Aanalizi”, Muhasebe ve Finansman Dergisi, 13 (51), 139-156.

Aydın, K. (2011), “Gelir, Konut, Sağlık ve Sosyal Güvenlik Açısından Türkiye'de Nispi Yoksulluk ve Hayat Standartları”, Business and Economics Research Journal, 2 (3), 189-206.

Aydın, S. (2003), “Türkiye'de Konut Sorununun Ekonomik Boyutları”, Yayınlanmamış Doktora Tezi, Ankara Üniversitesi, Sosyal Bilimler Enstitüsü, Kamu Yönetimi ve Siyaset Bilimi (Kent ve Çevre Bilimleri) A.B.D.

Balamir, M. (2010), “Türkiye Kentlerinde Toplu Yenileme: Dönüşüm-Mönüşüm”, $T M M O B$ Mimarlar Odası Ankara Şubesi, Eylül, Dosya, 13-25.

Bayındırlık ve İskân Bakanlığı (2009), “Kentleşme Şurası 2009”, Kentsel Dönüşüm, Konut ve Arsa Politikalarl Komisyonu Raporu, Nisan, Ankara, $<$ http://www.bayindirlik.gov.tr/turkce/kentlesme/kitap3.pdf>, 13.01.2012.

Bayraktar, E. (2007), Bir İnsanlık Hakkı Konut: TOKI'nin Planlı Kentleşme ve Konut Üretim Seferberliği, 1. Baskı, Boyut Yayıncılık, İstanbul.

Bayraktar, E. (2008), “Gayrimenkul Zirvesi 8'da Konuşma”, GYODER, 04-05.06.2010, Panel Kitabl, s. 7-11.

Bayraktar, E. (2009), “Gayrimenkul Zirvesi 9'da Konuşma”, GYODER, 03-04.06.2010, Panel Kitabi, s. 20-27.

Bayraktar, E. (2010), “Gayrimenkul Zirvesi 10'da Konuşma”, GYODER, 15-17.06.2010, Panel Kitabl, s. 15-17.

Bilgin, İ. (2002), Türkiye’nin Modernleşme Süreci İçinde Konut Üretimi, $<$ http://www.arkitera.com.tr/platform/konut/ihsanbilgin1.htm>, 13.05.2012.

Birleşmiş Milletler (2008), Housing Finance Mechanisms in India (United Nations Human Settlements Program, UN-HABITAT), Nairobi, Kenya.

Birleşmiş Milletler (2010), Report 2010, (United Nations Economic Commission for Europe, UNECE), Geneva, İsviçre.

Coşkun, Y. (2010), "Küresel Finansal Kriz ve Kredilendirme ve Değerleme Sorunları: ABD ve Türk İpotekli Konut Finansman Sistemleri Hakkında Bir Değerlendirme”, Taşınmaz Değerleme Günleri 2009, TMMOB Harita ve Kadastro Mühendisleri Odası İstanbul Şubesi, 21Kasım 2009, 223-249.

Coşkun, Yener (2011a), "The Global Financial Crisis and the Turkish Housing Market: Is There a Success Story?", Housing Finance International, 25 (3): 6-14.

Coşkun, Y. (2011b), "The Establishment of the Real Estate Regulation and Supervision Agency of Turkey (RERSAT)”, Housing Finance International, 25 (4): 42-51. 
Coşkun, Y. (2011c), "Does Re-design of the Policies on Housing Finance and Supply Help to Solve Housing Question of Turkey”, 18 th Annual ERES Conference, 15-18.06.2011, Eindhoven, Hollanda, <http://papers.ssrn.com/sol3/papers.cfm?abstract_id=1868758>, 11.10.2012.

Coşkun, Y. (2013a), “Türkiye'deki Kurumsal Konut Finansman Sisteminin Analizi”, Yayımlanmamış Doktora Tezi, Ankara Üniversitesi, Fen Bilimleri Enstitüsü, Taşınmaz Geliştirme A.B.D.

Coşkun, Y. (2013b), Housing finance in Turkey in last 25 Years: good, bad or ugly?, Working Paper, EMF-ENHR (Housing Finance Working Group) Seminar, September 17 th. Brussel, Belgium.

Çiloğlu, İ. (1998), “Kayıt dışı ekonominin işleyişi ve kamu bütçesine etkisi”, Hazine Dergisi, No. 11 (Temmuz), 67-91.

De Soto, H. (2000), The mystery of capital, (Çev. Aygen, M. 2005. Sermayenin Sırrı), Ankara: Liman Kitapları.

Demir, H. \& V.K. Palabıyık (2005), “Konut Ediniminde Uzun Vadeli İpotek Kredisi Sistemi”, HKM Jeodezi Jeoinformasyon ve Arazi Yönetimi Dergisi, No. 2005/92,

<www.hkmo.org.tr/resimler/ekler /9cb3ea 317a_ek.pdf>, 14.02.2011.

D.P.T. (2001), Sekizinci Beş Yıllık Kalkınma Planı Konut Özel İhtisas Komisyonu Raporu, No. 2594ÖİK: 606, <www.dpt.gov.tr>, 20.10.2012.

D.P.T. (2006), Dokuzuncu Kalkınma Planı (2007-2013), <http://esk.dpt.gov.tr/>, 18.02.2014.

D.P.T. (2013), Onuncu Kalkınma Planı (2014-2018), <http://esk.dpt.gov.tr/>, 18.02.2014.

Dünya Bankası (1993), "Housing: Enabling Markets to Work", Policy Paper, Washington, D.C.

Dünya Bankası ve Devlet İstatistik Kurumu (DİE) (2005), Turkey joint poverty assessment report, Volume I. August 8, <www.worldbank.org.tr>, 25.10.2012.

Erbaş, S.N. \& E.N. Frank (2002), “The Role of Affordable Mortgages in Improving Living Standards and Stimulating Growth: A Survey of Selected MENA Countries", Working Paper, WP/02/17, IMF.

Erder, S. (2007), "Kentsel Arsa ve Konut Üretim Sürecinde 'Kırsal Alışkanlıklar ve Kural'ların Etkisi”, Ruşen Keleş'e Armăgan - 2, Kent ve Planlama - Geçmişi Korumak Geleceği Tasarlamak, (der. Ayşegül Mengi), Ankara: İmge, 267-283.

Erman, T. (2001), "The Politics of Squatter (Gecekondu) Studies in Turkey: The Changing Representations of Rural Migrants in the Academic Discourse", Urban Studies, Vol. 38, No: 7, 983-1002.

European Mortgage Federation (2007), Hypostat 2006: A Review of Europe's Mortgage and Housing Markets, November.

Fannie Mae (1992), "Creating a market oriented housing finance system in Turkiye", Volume I: Final Report and Appendices, A1-A4, March. 
Geray, C. (2010), TOKİ Gerçeği Paneli, TMMOB Harita ve Kadastro Mühendisleri Odası İstanbul Şubesi, 6 Mart 2009: 8-9, <http://www.hkmo.org.tr/yayinlar/kitap_listele.php?sube=6>, 18.06.2012.

Gilbert, A. (1994), "Third World Cities: Poverty, Employment, Gender Roles and the Environment During a Time of Restructuring, Urban Studies, Vol. 31, 605-633.

Gürbüz, A. (2002), “İpotekli Konut Kredileri ve Türkiye'de Uygulaması”, Uzmanlık Tezi, TCMB, $<$ www.tcmb.gov.tr>, 20.01.2012.

Hazine Müsteşarlığı (2010), Kamu İşletmeleri Raporu 2009, Ekim.

Hoek-Smit, M. C. (2009), "Housing Finance Subsidies", Eds.: Chiquier, L. \& M. Lea, Housing Finance Policy in Emerging Markets, The World Bank, Washington D.C, 417-459.

Karpat, K.H. (2004), “The Genesis of the Gecekondu: Rural Migration and Urbanization (1976)”, European Journal of Turkish Studies, Thematic Issue $\mathrm{N}^{\circ} 1$ - Gecekondu, $<$ http://www.ejts.org/document54.html>, 20.05.2012.

Keleş, R. (2006), Kentleşme Politikası, 10. Baskı, İmge Kitabevi, Ankara.

Keleş, R. (2010), TOKİ Gerçeği Paneli, TMMOB Harita ve Kadastro Mühendisleri Odası İstanbul Şubesi, 6 Mart 2009, 5-8, <http://www.hkmo.org.tr/yayinlar/kitap_listele.php?sube=6>, 18.02.2012.

Kongar, E. (2003), 21. Yüzyılda Türkiye: 2000'li Yıllarda Türkiye'nin Toplumsal Yapısı, 32. Basım, Remzi Kitabevi, İstanbul.

Konut Müsteşarlığı (2003), Türkiye Konut Sahipliği Çalışması, Şubat, APK Daire Başkanlığı, $<$ http://www.konut.gov.tr/html/raporveekleri/tksa.doc>, 14.05.2012.

Lea, M.J. (2009), "Structure and Evolution of Housing Finance System”, Eds.: Chiquier, Loïc \& Michael J. Lea, Housing Finance Policy in Emerging Markets, The World Bank, Washington D.C., 29-47.

McKinsey Global Institute (2003), Turkey: Making the Productivity and Growth Breakthrough, February, <www.mckinsey.com/mgi/reports/pdfs/turkey/turkey.pdf>, 30.11.2011.

Mengi, A. \& R. Keleş (2003), İmar Hukukuna Giriş, İmge Kitabevi, Ankara.

Painter, G. \& C.L. Redfearn (2001), The Role of Interest Rates in Influencing Long-Run Homeownership Rates, <http://www.usc.edu/schools/sppd/lusk/research/pdf/wp_20011011.pdf>, 30.12.2011.

Sayıştay Başkanlığı (2013), Toplu Konut İdaresi Başkanlı̆̆ 2012 Yllı Raporu, $<$ http://www.sayistay.gov.tr/rapor/kit/2012/47toki.pdf>, 17.02.2014.

Sarı, Ö.B.Ö. (2007), "Mevcut Konut Stokunda Yeniden Yatırım: Hanehalkı Davranışının Üst Ölçekli Etkileri”, Planlama Dergisi, Say1 2, 35-42.

Schmidt, S. \& V. Budinich (2006), "Housing the Poor by Engaging the Private and Citizen Sectors: Social Innovations and Hybrid Value Chains", World Urban Forum, Vancouver, Canada, $<$ http://www.globalurban.org/GUDMag08Vol4Iss2/SchmidtBudinich.htm>, 22.02.2012. 
Schmitz, A. \& D.L. Brett (2007), Real Estate Market Analysis: A Case Study Approach, Fifth Edition, Urban Land Institute.

Shinozaki, S. (2005), “A Comparative Assessment of Housing Finance Markets in Transition Economies", içinde: Housing Finance Markets in Transition Economies: Trends and Challenges, OECD, 7-82.

Shuid, S. (2010), "Low Income Housing Allocation System in Malaysia: Managing Housing Need for the Poor", ENHR 22nd International Housing Research Conference, 4-7 July, İstanbul.

Tekeli, İ. (1982), “Türkiye'de Konut Sunumunun Davranışsal Nitelikleri ve Konut Kesiminde Bunalım”, Kent-Koop: Konut 81, Ankara: 57-101; içinde: Tekeli, İ. (2010), Konut Sorununu Konut Sunum Biçimleriyle Düşünmek, Tarih Vakfı Yurt Yayınları, İlhan Tekeli Toplu Eserler 13, Birinci Basım, İstanbul, 174-220.

Tekeli, İ. (1994), "Bir Ülkede Konut Sorununun Yanlış Tanımlandığı Konusunda Kuşkular Belirdi Mi Konut Sorunu Çözüme Yaklaşmış Demektir”, Mimarlık Dergisi, Yı1: 32, Sayı: 260, Kasım, 27-28; içinde: Tekeli, İ. (2010), Konut Sorununu Konut Sunum Biçimleriyle Düşünmek, Tarih Vakfı Yurt Yayınları, İlhan Tekeli Toplu Eserler 13, Birinci Basım, İstanbul, 121-123.

TOKİ (2010a), TOKİ Kurum Profili 2009-2010, <www.toki.gov.tr>.

TOKİ (2010b), Konut Edinme Rehberi 2010, <www.toki.gov.tr>.

Tübitak (2003), Vizyon 2023 Teknoloji Öngörüsü Projesi İnşaat ve Alt Yapı Paneli Raporu, $<$ http://www.tubitak.gov.tr/tubitak_content_files/vizyon2023/ia/insaat_son_surum.pdf $>$, 03.07.2012.

TÜİK (2001), Bina Sayımı 2000, <http://www.tuik.gov.tr/Kitap.do?metod =KitapDetay\&KT _ID=9\&KITAP_ID=64>, 29.11.2012.

TÜİK (2011), Türkiye Istatistik Yılliğ

TÜİK (2013), "Nüfus ve konut araştırması 2011”, Haber Bülteni, No: 15843, 31 Ocak 2013, TÜİK.

Türel, Ali (2012), "High Housing Production Under Less Regulated Market Conditions in Turkey”, ERES 19 thAnnual Conference, Working Paper, 13-16 Haziran 2012, İskoçya, $<$ http://eres2012.com/>, 12.07.2012.

Türk, Ş.Ş. \& W.K.K. Altes (2010), "The Planning System and Land Provision for Social Housing in Turkey”, Housing Finance International, (Autumn), 26-32.

Üçışık, H.F. (2006), Konut Sorunu ve Çözüm Önerileri, Ötüken Neşriyat, İstanbul.

Ülger, E. (2004), “İmara Aykırı ve Kaçak Yapılaşmış Alanlarda Taşınmaz Geliştirme Seçeneği”, İstanbul Üniv. Müh. Fak. Yerbilimleri Dergisi, Cilt 17, Sayı 1, 57-67.

Warnock, V.C. \& F.E. Warnock (2008), "Markets and Housing Finance”, Journal of Housing Economics, Vol. 17, 239-251. 
Whitehead, C. M.E. (2007), "Planning Policies and Affordable Housing: England as a Successful Case Study", Housing Studies, 22 (1): 25-44.

Whitehead, C. M.E. \& K. Scanlon (2002), "Fiscal instruments for the provision of affordable housing", ENHR Conference, Vienna. 1-5 July, <http://eprints.lse.ac.uk/30053/>, 12.07.2011. 